Review

\title{
Circular RNAs in Sudden Cardiac Death Related Diseases: Novel Biomarker for Clinical and Forensic Diagnosis
}

\author{
Meihui Tian ${ }^{1,+}$, Zhipeng Cao ${ }^{2,+}$ (i) and Hao Pang ${ }^{1, *}$ \\ 1 Department of Forensic Genetics and Biology, School of Forensic Medicine, China Medical University, \\ No.77 Puhe Road, Shenyang North New Area, Shenyang 110122, China; tianmh0619@163.com \\ 2 Department of Forensic Pathology, School of Forensic Medicine, China Medical University, No.77 Puhe Road, \\ Shenyang North New Area, Shenyang 110122, China; zpcao@cmu.edu.cn \\ * Correspondence: hpang@cmu.edu.cn; Tel.: +86-24-31939435 \\ + These authors contributed equally to this work.
}

Citation: Tian, M.; Cao, Z.; Pang, H. Circular RNAs in Sudden Cardiac Death Related Diseases: Novel Biomarker for Clinical and Forensic Diagnosis. Molecules 2021, 26, 1155 https://doi.org/10.3390/ molecules 26041155

Academic Editor: Mário Barroso

Received: 22 January 2021

Accepted: 18 February 2021

Published: 21 February 2021

Publisher's Note: MDPI stays neutral with regard to jurisdictional claims in published maps and institutional affiliations.

Copyright: () 2021 by the authors. Licensee MDPI, Basel, Switzerland. This article is an open access article distributed under the terms and conditions of the Creative Commons Attribution (CC BY) license (https:// creativecommons.org/licenses/by/ $4.0 /)$.

\begin{abstract}
The prevention and diagnosis of sudden cardiac death (SCD) are among the most important keystones and challenges in clinical and forensic practice. However, the diagnostic value of the current biomarkers remains unresolved issues. Therefore, novel diagnostic biomarkers are urgently required to identify patients with early-stage cardiovascular diseases (CVD), and to assist in the postmortem diagnosis of SCD cases without typical cardiac damage. An increasing number of studies show that circular RNAs (circRNAs) have stable expressions in myocardial tissue, and their time- and tissue-specific expression levels might reflect the pathophysiological status of the heart, which makes them potential CVD biomarkers. In this article, we briefly introduced the biogenesis and functional characteristics of circRNAs. Moreover, we described the roles of circRNAs in multiple SCD-related diseases, including coronary artery disease (CAD), myocardial ischemia or infarction, arrhythmia, cardiomyopathy, and myocarditis, and discussed the application prospects and challenges of circRNAs as a novel biomarker in the clinical and forensic diagnosis of SCD.
\end{abstract}

Keywords: circular RNA; biomarker; sudden cardiac death; diagnosis; forensic

\section{Introduction}

Cardiovascular disease (CVD) is the most lethal noncommunicable disease, it globally being the greatest contributor to high morbidity and mortality [1-3]. Irregular cardiac activities restrict the blood supply, leading to sudden unexpected death caused by loss of cardiac function, known as sudden cardiac death (SCD) [4]. Globally, SCD accounts for 4-5 million deaths per year, and a considerable number of $S C D$ events occur in asymptomatic individuals $[1,3]$. Clinically, due to the extremely rapid pathological process of SCD, most victims die within $1 \mathrm{~h}$ or even a few minutes of symptom onset, and survival rates remain low; thus, predicting and preventing the occurrence of SCD are the focus of clinical CVD [5-8]. In forensic practice, SCD identification is also one of the most important keystones and challenges, while autopsy can be completely negative in many cases, which needs further study [9]. Thus, the detection of novel biomarkers for SCD is urgently needed both in clinical and forensic medicine.

Many classical and novel biomarkers have emerged for predicting SCD, including protein, functional, and genetic biomarkers [1,10-12]. In 1976, Sanger and colleagues first introduced circular RNA (circRNA) in plant viroids and found that it has a special circular structure [13]. With the rapid advancements in biochemical methods, and the usage of highthroughput sequencing and microarray technologies, circRNAs are a research focus due to their unique structural and functional characteristics $[14,15]$. Since the 1990s, researchers have discovered more than 32,000 circRNAs from mammals, and their biological functions and mechanisms of action were gradually revealed [16-21]. The biological functions of circRNAs are continuously discovered and confirmed, mainly including the "miRNA 
sponge", regulating transcription and gene expression, and regulating and encoding proteins [22-25]. Nowadays, the regulatory potential of circRNAs in the cardiovascular system is a hot topic and circRNAs, have emerged as novel players in diagnostic and therapeutic strategies for CVDs [26].

This review briefly introduces the biosynthesis and characteristics of circRNAs, and summarizes recent advances in the role of circRNAs in SCD-related diseases. Lastly, we focus on the potential of circRNAs as biomarkers in the clinical and forensic diagnosis of $\mathrm{SCD}$, and discuss the current challenges, prospects, and directions for future research.

\section{Introduction of CircRNA}

CircRNAs are a member of the non-coding RNAs (ncRNAs) family, formed by linear precursor message RNA (pre-mRNA) through reverse splicing [14]. Originally, circRNA was considered to be secondary byproducts of linear message RNA (mRNA). However further research has demonstrated that circRNA is an important product of pre-mRNA processing, and the processing mechanism of circRNA could compete with that of mRNA [27]. The covalently closed-loop structure of circRNAs, also known as backsplicing, is formed by the joining of the $3^{\prime}$ splice site to the $5^{\prime}$ splice site of mRNA [27,28]. Two models of circRNA biogenesis through backsplicing were first proposed by Jeck et al. in 2013, lariat-driven and intron-pairing-derived circularization (direct backsplicing), which sparked a new line of research into circRNA biogenesis [29]. The lariat precursor is also called exon skipping, which means that, during pre-mRNA synthesis, RNA is folded so that multiple exons are close to each other, forming a circular RNA intermediate, and then generate circRNA by lariat-like splicing (Figure 1A) [30]. In the direct backsplicing model, flanking intronicsequence (such as the ALU sequence) complementarity leads to the formation of secondary structures in the pre-mRNA transcript, which primes the molecule for splicing via the appositional placing of two distant exons (Figure 1B) [28,29]. In addition, some scholars proposed relying on the cyclization mode of RNA-binding proteins (RBP), such as RNA polymerase II, the quaking protein, or the muscleblind protein, which can be combined with the RNA sequence, thereby promoting circRNA formation (Figure 1C) [27,31-33].

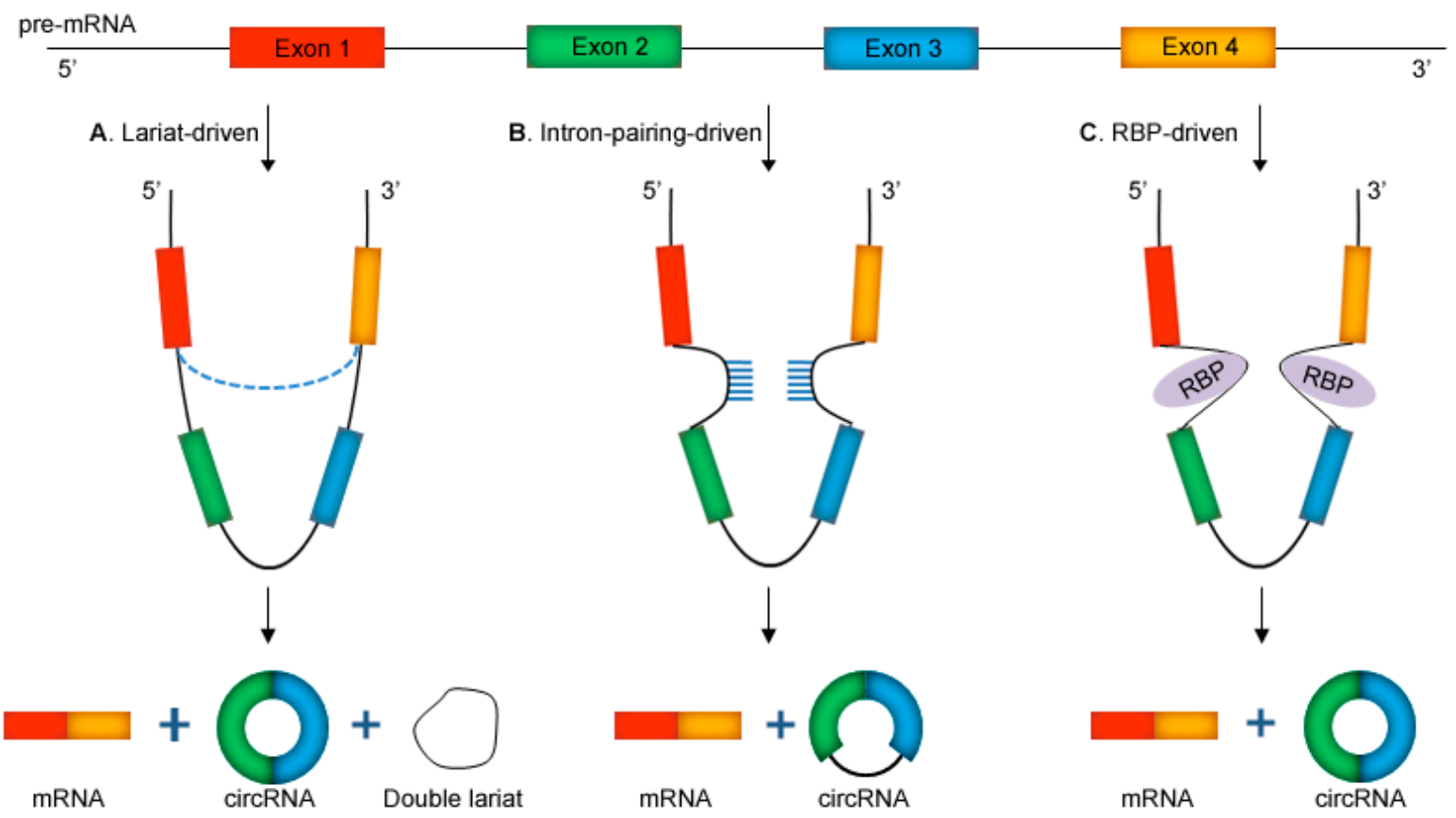

Figure 1. Biogenesis of circRNAs. (A) Lariat-driven model; (B) intron-pairing-driven model; (C) RNA-binding proteins (RBP)-driven model. 
CircRNAs can be classified into three groups depending on their mode of biogenesis and their sequence: Exonic circular RNAs (ecircRNAs), intronic circular RNAs (ciRNAs), and exon-intron circular RNAs (EIciRNAs) [23,24,34,35]. EcircRNAs are only derived from exons in linear transcripts, and lack any introns in their sequences. The majority of circRNAs belong to this group and predominantly exist in the cytoplasm. In contrast, ciRNAs are not generated through backsplicing and lack exonic sequences. CiRNAs exist in the nucleus and have little enrichment for microRNA (miRNA) target sites. EIciRNAs contain both introns and exons in their sequences, which are mainly located in the nucleus. According to the circRNA location in the genome, circRNAs can also be grouped into intragenic and intergenic [36]. EcircRNAs, EIciRNAs, and ciRNAs are all intragenic circRNAs, which arise from sequences within the parental gene locus. CircRNAs derived from different genome intervals are collectively called intergenic circRNAs.

One of the most different features of circRNAs is the closed-loop structure, which is distinguished from that of other linear RNA molecules. Thus, circRNAs are insusceptible to gradation by RNA exonucleases and more stable compared to linear RNA molecules [19]. Researchers demonstrated that the average half-life of circRNAs can reach $50 \mathrm{~h}$, which is a potential advantage of being biomarkers [37]. CircRNAs are conserved in mammals, and their expression exhibits tissue and disease specificity [20,38-40]. Sequencing results suggested that the most abundant circRNAs are expressed in the nervous system, heart, and tumor tissue [41-43]. The different expressions of circRNAs in myocardial tissue or body fluids by RNA sequencing or microarray analysis are summarized in Table 1. Werfel et al. found more than 9000 circRNAs in the hearts of rats, mice, and humans under different physiological and pathological conditions [20]. Results showed that about $30 \%$ circRNAs were conversed between mice and rats, and about $10 \%$ were conversed in all three species. In another study, researchers extracted 15,318 and 3017 specific circRNAs from 12 human heart-tissue samples and 25 mouse heart-tissue samples, respectively [44]. These results indicate that there is a large number of stable and highly expressed circRNAs in the human cardiovascular system, which suggests biomarker potential in CVDs. Furthermore, recent studies showed that circRNAs can be stably enriched in exosomes, and are widely present in body fluids such as blood, urine, saliva, and semen, which also lays a solid foundation for them being biomarkers [45].

Table 1. Different expressions of circRNAs in sudden cardiac death (SCD) related diseases by RNA sequencing or microarray analysis.

\begin{tabular}{|c|c|c|c|c|c|c|c|c|c|}
\hline \multirow[t]{2}{*}{ Diseases } & \multirow[t]{2}{*}{ Species } & \multirow[t]{2}{*}{ Samples } & \multirow{2}{*}{$\begin{array}{c}\text { Sample } \\
\text { Capacity } \\
\text { Case/Control }\end{array}$} & \multirow[t]{2}{*}{ Technique } & \multicolumn{3}{|c|}{$\begin{array}{l}\text { Expression } \\
\text { Regulation }\end{array}$} & \multirow{2}{*}{$\begin{array}{l}\text { Representative } \\
\text { CircRNAs }\end{array}$} & \multirow[t]{2}{*}{ Reference } \\
\hline & & & & & DE & UR & DR & & \\
\hline CAD & human & PBMC & $70 / 30$ & sequence & 2368 & 2283 & 85 & $\begin{array}{l}\text { hsa_circ_0003915, } \\
\text { hsa_circ_001272, } \\
\text { hsa_circ_0103771, } \\
\text { hsa_circ_0006251, } \\
\text { hsa_circ_0066529, } \\
\text { hsa_circ_0030042 }\end{array}$ & [46] \\
\hline CAD & human & PB & $20 / 20$ & microarray & 110 & 73 & 37 & $\begin{array}{l}\text { hsa_circ_0030769, } \\
\text { hsa_circ_0079828, } \\
\text { hsa_circ_15486-161, } \\
\text { hsa_circ_0122274, } \\
\text { hsa_circ_16316-13, } \\
\text { hsa_circ_0140538 }\end{array}$ & [47] \\
\hline CAD & human & PB & $5 / 5$ & microarray & 3423 & - & - & $\begin{array}{l}\text { hsa_circ_0125589, } \\
\text { hsa_circ_0001946, } \\
\text { hsa_circ_0008507 }\end{array}$ & [48] \\
\hline
\end{tabular}


Table 1. Cont.

\begin{tabular}{|c|c|c|c|c|c|c|c|c|c|}
\hline \multirow[t]{2}{*}{ Diseases } & \multirow[t]{2}{*}{ Species } & \multirow[t]{2}{*}{ Samples } & \multirow{2}{*}{$\begin{array}{c}\text { Sample } \\
\text { Capacity } \\
\text { Case/Control }\end{array}$} & \multirow[t]{2}{*}{ Technique } & \multicolumn{3}{|c|}{$\begin{array}{l}\text { Expression } \\
\text { Regulation }\end{array}$} & \multirow{2}{*}{$\begin{array}{l}\text { Representative } \\
\text { CircRNAs }\end{array}$} & \multirow[t]{2}{*}{ Reference } \\
\hline & & & & & DE & UR & DR & & \\
\hline CAD & human & PB & $12 / 12$ & microarray & 22 & 12 & 10 & $\begin{array}{l}\text { hsa_circ_0082081, } \\
\text { hsa_circ_0113854, } \\
\text { hsa_circ_0124644, } \\
\text { hsa_circ_0098964, } \\
\text { hsa-circRNA5974-1 }\end{array}$ & [49] \\
\hline CAD & human & PBMC & $24 / 7$ & microarray & 795 & 624 & 171 & $\begin{array}{l}\text { hsa_circ_0001879, } \\
\text { hsa_circ_0004104, } \\
\text { hsa_circ_004432 }\end{array}$ & {$[50]$} \\
\hline CAD & human & PB & $6 / 6$ & microarray & 40 & 13 & 27 & $\begin{array}{l}\text { hsa_circRNA11783-2, } \\
\text { hsa_circRNA6510-1 }\end{array}$ & [51] \\
\hline MI & mouse & Myo & $2 / 2$ & microarray & 82 & 41 & 41 & mmu_circ_0001113 & [52] \\
\hline MIR & rat & Myo & $2 / 2$ & sequencing & 69 & 36 & 33 & $\begin{array}{l}\text { rno_circ_0000112, } \\
\text { rno_circ_0005562, } \\
\text { rno_circ_0008515 }\end{array}$ & [53] \\
\hline MIR & mouse & Myo & $3 / 3$ & sequencing & 21 & 14 & 7 & $\begin{array}{l}\text { novel_circ_0020886, } \\
\text { novel_circ_0008516, } \\
\text { novel_circ_0002498 }\end{array}$ & [54] \\
\hline MIR & mouse & Myo & $1 / 1$ & microarray & - & - & - & mmu_circ_006636 & [55] \\
\hline MIR & mouse & PCM & $1 / 1$ & microarray & - & - & - & $\begin{array}{l}\text { mmu_circ_400095, } \\
\text { mmu_circ_101512, } \\
\text { mmu_circ_100714, } \\
\text { mmu_circ_405755, } \\
\text { mmu_circ_101237 }\end{array}$ & {$[56]$} \\
\hline $\mathrm{AF}$ & human & Myo & $3 / 3$ & microarray & 736 & 537 & 199 & $\begin{array}{l}\text { hsa_circ_100612, } \\
\text { hsa_circ_405917 }\end{array}$ & [57] \\
\hline $\mathrm{AF}$ & human & Atr & $7 / 7$ & sequencing & 280 & 46 & 234 & $\begin{array}{l}\text { hsa_circ_24801, } \\
\text { hsa_circ_16247 }\end{array}$ & [58] \\
\hline $\mathrm{AF}$ & human & left-Atr & $8 / 6$ & sequencing & 40 & - & - & $\begin{array}{l}\text { hsa_circ_0025470, } \\
\text { hsa_circ_0035132, } \\
\text { hsa_circ_0035148, } \\
\text { hsa_circ_0057344, } \\
\text { hsa_circ_0112651, } \\
\text { hsa_circ_0112664 }\end{array}$ & [59] \\
\hline $\mathrm{AF}$ & human & Atr & $9 / 6$ & sequencing & 108 & 51 & 57 & $\begin{array}{l}\text { hsa_circ_20118, } \\
\text { hsa_circ_17558, } \\
\text { hsa_circ_16688 } \\
\text {,hsa_circ_11109, } \\
\text { hsa_circ_11017, } \\
\text { hsa_circ_11058 }\end{array}$ & [60] \\
\hline $\mathrm{AF}$ & human & Atr & $9 / 6$ & sequencing & 147 & 102 & 45 & $\begin{array}{l}\text { hsa_circ_0005643, } \\
\text { novcl_circ_0026284, } \\
\text { novel_circ_0077334, } \\
\text { novel_circ_0046852, } \\
\text { novel_circ_0068696, } \\
\text { novel_circ_0055884 }\end{array}$ & [61] \\
\hline \multirow{3}{*}{$\mathrm{AF}$} & \multirow{3}{*}{ human } & \multirow{3}{*}{ Atr } & \multirow{3}{*}{$10 / 10$} & \multirow{3}{*}{ sequencing } & 478 (left) & 374 & 104 & \multirow{3}{*}{$\begin{array}{c}\text { hsa_circ_0004270, } \\
\text { hsa_circ_0000075, } \\
\text { hsa_circ_0030254, } \\
\text { hsa_circ_0007271, } \\
\text { chr6:129371063- } \\
129419560\end{array}$} & \multirow{3}{*}{ [62] } \\
\hline & & & & & 535 (right) & 267 & 268 & & \\
\hline & & & & & 23 (both) & 20 & 3 & & \\
\hline
\end{tabular}


Table 1. Cont

\begin{tabular}{|c|c|c|c|c|c|c|c|c|c|}
\hline \multirow[t]{2}{*}{ Diseases } & \multirow[t]{2}{*}{ Species } & \multirow[t]{2}{*}{ Samples } & \multirow{2}{*}{$\begin{array}{c}\text { Sample } \\
\text { Capacity } \\
\text { Case/Control }\end{array}$} & \multirow[t]{2}{*}{ Technique } & \multicolumn{3}{|c|}{$\begin{array}{l}\text { Expression } \\
\text { Regulation }\end{array}$} & \multirow{2}{*}{$\begin{array}{l}\text { Representative } \\
\text { CircRNAs }\end{array}$} & \multirow[t]{2}{*}{ Reference } \\
\hline & & & & & DE & UR & DR & & \\
\hline $\mathrm{AF}$ & human & Atr & $4 / 4$ & sequencing & 296 & 238 & 58 & $\begin{array}{l}\text { hsa_circ_002085, } \\
\text { hsa_circ_001321 }\end{array}$ & [63] \\
\hline $\mathrm{AF}$ & human & blood & $15 / 15$ & microarray & 31 & 24 & 7 & $\begin{array}{l}\text { hsa_circ_025016, } \\
\text { hsa_circ_404686, } \\
\text { hsa_circR_000367, } \\
\text { hsa_circ_001729, } \\
\text { hsa_circ_100790, } \\
\text { hsa_circ_030162, } \\
\text { hsa_circ_100789, } \\
\text { hsa_circ_104270, } \\
\text { hsa_circ_102049 }\end{array}$ & [64] \\
\hline $\mathrm{HCM}$ & human & LV & $2 / 2$ & sequencing & 60 & 34 & 26 & $\begin{array}{c}\text { hsa_circ_0003101, } \\
\text { chr9:108484902- } \\
108467878\end{array}$ & [33] \\
\hline DCM & human & LV & $2 / 2$ & sequencing & 43 & 15 & 28 & $\begin{array}{c}\text { chr4:121675708- } \\
\text { 121732604, } \\
\text { chr2:179542852- } \\
179586861\end{array}$ & [33] \\
\hline DCM & human & $\begin{array}{l}\text { hiPSC- } \\
\text { CMs }\end{array}$ & $26^{1}$ & sequencing & - & - & - & $\begin{array}{l}\text { circNCX1, } \operatorname{circCHD} 7, \\
\text { circATXN10, } \\
\text { circDNAJ6C }\end{array}$ & [65] \\
\hline DOXIC & human & Myo & $10 / 17^{2}$ & microarray & - & - & - & hsa_circ_0004214 & [66] \\
\hline DOXIC & human & Myo & $3 / 3$ & sequencing & 356 & 207 & 149 & hsa_circ_0001141 & [67] \\
\hline diabetic CM & mouse & Myo & $4 / 4$ & microarray & 43 & 24 & 19 & mmu_circ_010567 & [68] \\
\hline diabetic CM & mouse & Мyo & $4 / 4$ & microarray & 76 & 45 & 31 & mmu_circ_000203 & [69] \\
\hline $\mathrm{ACM}$ & mouse & Myo & $3 / 3$ & microarray & 265 & 114 & 151 & $\begin{array}{l}\text { mmu_circ_011978, } \\
\text { mmu_circ_011979, } \\
\text { mmu_circ_011977, } \\
\text { mmu_circ_011982, } \\
\text { mmu_circ_011976, } \\
\text { mmu_circ_011975, }\end{array}$ & [70] \\
\hline $\begin{array}{l}\text { fulminant } \\
\text { myocarditis }\end{array}$ & human & PB & $3 / 3$ & microarray & 3172 & 2281 & 892 & $\begin{array}{l}\text { hsa_circ_0071542, } \\
\text { hsa_circ_0014350, } \\
\text { hsa_circ_0073029 }\end{array}$ & [71] \\
\hline
\end{tabular}

${ }^{1}$ Differentiation time course (0-17 day), 3 replicates each; ${ }^{2}$ neonatal/mature postnatal human. Abbreviation: DE, different expression; UR, up-regulated; DR, down-regulated; CAD, coronary artery disease; MI, myocardial infarction; MIR, myocardial ischemia/reperfusion; HCM, hypertrophic cardiomyopathy; DCM, dilated cardiomyopathy; DOXIC, doxorubicin-induced cardiomyopathy; CM, cardiomyopathy ACM, alcoholic cardiomyopathy; PBMC, peripheral blood mononuclear cell; PB, peripheral blood; PBL, peripheral blood; Myo, myocardial tissues; LV, left ventricle; Atr, atrial tissues; PCM, primary cardiomyocyte; hiPSC-CMs, human induced pluripotent stem cell derived cardiomyocytes.

\section{CircRNA Serves as Biomarkers in SCD-Related Diseases}

\subsection{Coronary Artery Disease}

The acute and persistent inadequate blood flow of coronary arteries may cause myocardial necrosis, which is known as myocardial infarction (MI). Worldwide, MI is the leading cause of mortality among all CVDs, and tends to occur in patients with coronary artery disease (CAD) [72]. With the development of high-throughput sequencing and chip technology, a large number of circRNAs related to CAD were discovered. Many circRNAs show strong involvement in the formation of atherosclerosis, such as circular antisense non-coding RNA (ANRIL) and circ_0003204 [73,74]. Yu and colleagues performed sequence 
analysis of circRNAs in the peripheral blood mononuclear cells of 70 CAD patients and 30 healthy controls, and identified 2283 downregulated and 85 upregulated circRNAs in total; many of the dysregulated circRNAs were involved in CAD pathophysiology [46]. Lin et al. divided CAD patients into control and test groups.On the basis of the results of routine inspection and the Gensini score, and found a total of 110 circRNAs to be differentially expressed in the two groups: 73 upregulated and 37 downregulated [47]. All these results indicated that circRNAs have critical roles in various biological CAD processes.

Research about circRNAs as potential biomarker for CAD is constantly developing (Table 2). A recent microarray study identified 3423 dysregulated circRNAs in five CAD patients and five matched healthy controls [48]. The expression levels of hsa_circ_0001946, hsa_circ_0008507 and hsa_circ_0000284 were significantly elevated in peripheral CAD blood leukocytes, consistent with their expressions in the peripheral blood, but exhibited significant differences in various populations. Zhao et al. analyzed circRNAs expression in peripheral blood of 12 CAD patients and 12 control individuals by RNA microarray, and found 22 differentially expressed circRNAs in CAD patients, including 12 upregulated and 10 downregulated circRNAs [49]. Among them, hsa_circ_0124644 expression was significantly upregulated in patients with CAD. The expression level was positively correlated with SYNTAX score and showed CAD diagnostic potential. Wang et al. found that a total of 624 circRNAs and 171 circRNAs were significantly upregulated and downregulated, respectively, in 24 CAD patients relative to 7 controls [50]. Hsa_circ_0001879 and hsa_circ_0004104 levels were significantly elevated, and the area under curve (AUC) was 0.703 and 0.700 , respectively. Hsa_circ_ 0001879 level was significantly positively correlated with blood pressure, while hsa_circ_0004104 level was negatively correlated with blood HDL-C level, which suggested that hsa_circ_0001879 and hsa_circ_0004104 may be closely related to the pathological process of CAD. The combination of these two circRNAs with CAD risk factors could better discriminate CAD patients from healthy controls. In 200 patients with suspected stable CAD referred for coronary computed tomographic angiography exam, hsa_circ_0001445 showed remarkable stability in clinical specimens [75]. The plasma levels of the hsa_circ_0001445 are lower in patients with higher coronary atherosclerosis extension and severity, and performed as a biomarker of stable CAD. Zou et al. [76] found that compared with the control group, the expression level of circTCF25 (hsa_circ_0041103) in peripheral blood mononuclear cells of CAD patients was significantly reduced, and was negatively correlated with fasting blood glucose, creatine kinase and Gensini score. The sensitivity and specificity of circTCF25 as a CAD biomarker were 0.60 and 0.61 , respectively. In addition, some researchers found that the expression of hsa_circRNA11783-2 was notably downregulated in the peripheral blood of patients with CAD and type 2 diabetes, predicting that it may serve as a "miRNA sponge" to adsorb miR-608 and miR-3907 to play a biological function [51,77].

\subsection{Myocardial Infarction}

In addition to coronary atherosclerosis, any other disease that can cause coronaryartery occlusion and subsequent loss of oxygen supply, such as coronary-artery vasospasm and anomalies can cause myocardial ischemia and even MI [79]. To identify circRNA expression changes in MI, scholars performed circRNA microarray analysis in sham and 3 days post-MI mouse hearts, and the expression of 1723 circRNAs was detected [52,80]. Of these, 82 circRNAs were consistently differentially expressed, including 41 upregulated circRNAs and 41 downregulated circRNAs. Among these, circFndc3b (mmu_circ_0001113) was significantly downregulated after validation by divergent primers and real-time RTqPCR. The human circFNDC3B (hsa_circ_0001361) ortholog was also significantly decreased in the cardiac tissues of ischemic cardiomyopathy patients. Further findings indicated that the modulation of circFNDC3B expression may represent a potential strategy to promote cardiac function and remodeling after MI. In another study with 642 acute myocardial infarction (AMI) patients, Vasout et al. identified that the expression levels of myocardial infarction-associated circular RNA (MICRA, hsa_circ_0000615) were lower in MI patients 
compared with those of 86 healt hy volunteers [81]. Patients with low levels of MICRA were at high risk of left ventricle (LV) dysfunction, and MICRA level in the peripheral blood could predict LV dysfunction in 3-4 months after MI. Afterwards, they tested whether MICRA could risk-stratify MI patients. MICRA improved risk classification after MI, and provided an incremental value of this novel biomarker in future prognostication strategies [82].

Table 2. The diagnosis value of circRNAs in SCD related diseases.

\begin{tabular}{|c|c|c|c|c|c|c|c|c|c|}
\hline \multirow[t]{2}{*}{ Diseases } & \multirow[t]{2}{*}{ CircRNA } & \multirow[t]{2}{*}{ Samples } & $\begin{array}{l}\text { Sample } \\
\text { Capacity }\end{array}$ & \multirow{2}{*}{$\begin{array}{l}\text { Expression } \\
\text { Regulation }\end{array}$} & \multirow[t]{2}{*}{ AUC (95\% CI) } & \multirow[t]{2}{*}{ Sensitivity } & \multirow[t]{2}{*}{ Specificity } & \multirow[t]{2}{*}{$p$-Value } & \multirow[t]{2}{*}{ Reference } \\
\hline & & & Case/Control & & & & & & \\
\hline CAD & hsa_circ_0001946 & PBL & $100 / 100$ & up & $0.71(0.64-0.79)$ & 0.85 & 0.52 & - & [48] \\
\hline CAD & hsa_circ_0000284 & PBL & $100 / 100$ & up & $0.68(0.61-0.76)$ & 0.66 & 0.71 & - & [48] \\
\hline CAD & hsa_circ_0008507 & PBL & $100 / 100$ & up & $0.75(0.68-0.82)$ & 0.86 & 0.60 & - & [48] \\
\hline CAD & hsa_circ_0124644 & PB & $115 / 137$ & up & $0.872(0.785-0.960)$ & 0.867 & 0.767 & $<0.001$ & [49] \\
\hline CAD & hsa_circ_0082081 & $\mathrm{PB}$ & $115 / 137$ & up & $0.66(0.522-0.798)$ & 0.833 & 0.433 & 0.033 & {$[49]$} \\
\hline CAD & hsa_circ_0113854 & PB & $115 / 137$ & up & $0.689(0.555-0.823)$ & 0.867 & 0.50 & 0.012 & [49] \\
\hline CAD & hsa_circ_0098964 & PB & $115 / 137$ & up & $0.82(0.707-0.933)$ & 0.80 & 0.867 & $<0.001$ & [49] \\
\hline CAD & hsa_circRNA5974-1 & $\mathrm{PB}$ & $115 / 137$ & up & $0.743(0.619-0.867)$ & 0.633 & 0.733 & 0.001 & [49] \\
\hline CAD & hsa_circ_0001879 & PBMC & $412 / 290$ & up & $0.703(0.656-0.750)$ & 0.831 & 0.543 & $<0.001$ & [50] \\
\hline CAD & hsa_circ_0004104 & PBMC & $412 / 290$ & up & $0.700(90.646-0.755)$ & 0.707 & 0.614 & $<0.001$ & [50] \\
\hline CAD & hsa_circRNA11783-2 & PBMC & $60 / 81$ & down & - & - & - & - & {$[51]$} \\
\hline CAD & hsa_circ_0001445 & $\mathrm{PB}$ & $74 / 126^{1}$ & down & $0.589(0.506-0.671)$ & - & - & $<0.001$ & {$[75]$} \\
\hline CAD & hsa_circ_0041103 & PBMC & $342 / 246$ & down & $0.62(0.57-0.67)$ & 0.60 & 0.61 & $<0.001$ & [76] \\
\hline $\mathrm{AF}$ & hsa_circ_025016 & plasma & $75 / 295$ & up & $0.802(0.798-0.806)$ & 0.794 & 0.776 & $<0.001$ & [64] \\
\hline $\mathrm{HCM}$ & circDNAJC6 & serum & $64 / 53$ & down & $0.819(0.725-0.912)$ & - & - & $<0.001$ & [78] \\
\hline $\mathrm{HCM}$ & circTMEM56 & serum & $64 / 53$ & down & $0.738(0.621-0.856)$ & - & - & $<0.001$ & {$[78]$} \\
\hline $\mathrm{HCM}$ & circMBOAT2 & serum & $64 / 53$ & down & $0.756(0.653-0.860)$ & - & - & $<0.001$ & [78] \\
\hline
\end{tabular}

${ }^{1}$ Stratified by segment stenosis score (SSS), SSS > 5 vs. SSS $\leq 5$. Abbreviation: CAD, coronary artery disease; AF, atrial fibrillation; HCM, hypertrophic cardiomyopathy; PBMC, peripheral blood mononuclear cell; PB, peripheral blood; PBL, peripheral blood.

The programed death of cardiomyocytes, including apoptosis and autophagy, critically contributes to the progressive loss of myocytes after the occlusion of a major epicardial coronary artery in MI [83]. Some circRNAs participate in the regulation of apoptosis, thereby regulating MI formation. For example, the expression of circACAP2 increased in cardiomyocytes after MI and promoted apoptosis by binding to miR-29 [84]. The circular RNA mmu_circ_0001878, also termed as Cdr1as, was derived from an antisense transcript of the cerebellar degeneration-related protein 1 gene at chromosome X (NC_000086.7) in mice $[22,85]$. Cdr1as was upregulated in MI mice with increased cardiac infarct size or cardiomyocytes under $6 \mathrm{~h}$ of hypoxia treatment [86]. Cdr1as overexpression could promote cell apoptosis and MI by mediating the regulation of miR-7a. Moreover, a recent study revealed that circ-Ttc3 (rno_circ_002317) was markedly upregulated in the ischemic myocardium of rats at 5 weeks post-MI, and in cardiomyocytes after being exposed to $6 \mathrm{~h}$ of ischemic insults [87]. The elevation of circ-Ttc3 expression protected cardiomyocytes against ischemia-related apoptotic death, while its downregulation aggravated cardiac dysfunction after MI, which seemed to be possible for the diagnostic and therapeutic targeting circ-Ttc3 in patients with ischemic heart disease (IHD). A recently discovered circRNA, circMACF1 (mmu_circ_0001258), was downregulated in the mouse myocardium at 3 days post-MI and in hypoxia-treated cardiomyocytes [88]. The overexpression of circMACF1 was effective in restoring cardiomyocyte apoptosis, and significantly reduced myocardial infarct size. Furthermore, Huang and colleagues found that circNfix (mmu_circ_0001704) level was decreased in the hearts of post-MI mouse, and its downregulation promoted cardiomyocyte proliferation and angiogenesis, and inhibited cardiomyocyte apoptosis after MI, which significantly attenuated cardiac dysfunction and improved prognosis [89]. 
Accordingly, circNfix might be a potent therapeutic target for restoring cardiac function and preventing heart failure after MI (Table 3).

Table 3. CircRNAs as potential biomarkers in myocardial infarction validated by real-time RT-qPCR.

\begin{tabular}{|c|c|c|c|c|c|}
\hline \multirow{2}{*}{ CircRNAs } & \multirow{2}{*}{ Samples } & \multirow{2}{*}{$\begin{array}{c}\text { Sample Capacity } \\
\text { Case/Control }\end{array}$} & \multirow{2}{*}{$\begin{array}{l}\text { Expression } \\
\text { Regulation }\end{array}$} & \multirow{2}{*}{ Functions } & \multirow{2}{*}{ Reference } \\
\hline & & & & & \\
\hline mmu_circ_0001113 & $3 \mathrm{~d}$ post-MI mice heart & $5 / 8$ & down & $\begin{array}{l}\text { induces cardiomyocyte } \\
\text { apoptosis and reduce } \\
\text { neovascularization }\end{array}$ & [52] \\
\hline hsa_circ_0000615 & $\begin{array}{l}\text { MI patient } \\
\text { whole blood }\end{array}$ & $327 / 86$ & down & $\begin{array}{c}\text { predicts of LV dysfunction, } \\
\text { improves risk classification } \\
\text { after MI }\end{array}$ & $\begin{array}{l}{[81]} \\
{[82]}\end{array}$ \\
\hline circACAP2 & MI rat heart & $-/-$ & up & promotes apoptosis & [84] \\
\hline mmu_circ_0001878 & $\begin{array}{l}24 \mathrm{~h} \text { post MI mice } \\
\text { heart }\end{array}$ & $10 / 10$ & up & $\begin{array}{l}\text { overexpression in vivo } \\
\text { increased cardiac infarct size }\end{array}$ & [86] \\
\hline rno_circ_002317 & $5 \mathrm{w}$ post-MI rats heart & $8 / 6$ & up & $\begin{array}{l}\text { restrains ischemic } \\
\text { cardiac injury }\end{array}$ & [87] \\
\hline mmu_circ_0001258 & $3 \mathrm{~d}$ post-MI mice heart & $6 / 6$ & down & $\begin{array}{l}\text { impairs the progression of } \\
\text { AMI by modulating the } \\
\text { miR-500b-5p/EMP1 axis }\end{array}$ & [88] \\
\hline mmu_circ_0001704 & $7 \mathrm{~d}$ post-MI mice heart & $6 / 6$ & down & $\begin{array}{l}\text { downregulation of it } \\
\text { promotes cardiomyocyte } \\
\text { proliferation and } \\
\text { angiogenesis, and inhibits } \\
\text { cardiomyocyte apoptosis } \\
\text { after MI }\end{array}$ & [89] \\
\hline
\end{tabular}

Abbreviation: MI, myocardial infarction.

\subsection{Myocardial Ischemia}

Though MI is the most frequent cause of IHD, an acute attack of myocardial ischemia without infarction can also lead to SCD [1]. However, studies about circRNAs involved in myocardial ischemia are rare, and most clinically referred to myocardial ischemia/reperfusion (MIR) injury (Table 4). In recent analysis of the circRNA expression profile in MIR rat models, a total of 10,387 circRNAs were identified, 69 circRNAs in the MIR group showed more than twofold differences compared with those in the sham group, and 28 circRNAs were detected to be differentially expressed in a protective group compared with those in the MIR group [53]. Among them, rno_circ_0000112, rno_circ_0005562, and rno_circ_0008515 were upregulated by MIR, but downregulated by protective group. Another study also detected that a total of 21 circRNAs were differentially expressed after $30 \mathrm{~min}$ ligation occlusion of the left anterior descending coronary artery, followed $4 \mathrm{~h}$ of reperfusion, namely, 14 upregulated circRNAs and 7 downregulated circRNAs [54]. Li et al. investigated the role of a circRNA transcribed from the sodium/calcium exchanger 1 (ncx1) gene, circNCX1 (mmu_circ_004295), with regard to heart function, cardiomyocyte apoptosis, and cardiac remodeling [90]. Results showed circNCX1 level was increased with the extension of the ligation time of the mouse heart and promoted cardiomyocyte apoptosis by acting as an endogenous miR-133a-3p sponge. Bai et al. confirmed that circular RNA DLGAP4 (circDLGAP4) levels were significantly decreased in the plasma of acute ischemic stroke patients (hsa_circ_0060180) and in a mouse stroke model (mmu_circ_0001098), and Wang et al. speculated that it might also act as a novel therapeutic target for MIR injury, which needs to be further proved by experimental evidence [91,92]. These findings suggest that circRNAs might contribute to MIR injury, and provide clues in circRNAs as novel biomarkers in myocardial ischemia diagnosis. 
Table 4. CircRNAs as potential biomarkers in myocardial ischemia models validated by real-time RT-qPCR.

\begin{tabular}{|c|c|c|c|c|c|c|}
\hline \multirow{2}{*}{$\begin{array}{l}\text { Disease } \\
\text { Models }\end{array}$} & \multirow{2}{*}{ CircRNAs } & \multirow{2}{*}{ Samples } & \multirow{2}{*}{$\begin{array}{c}\text { Sample Capacity } \\
\text { Case/Control }\end{array}$} & \multirow{2}{*}{$\begin{array}{l}\text { Expression } \\
\text { Regulation }\end{array}$} & \multirow{2}{*}{ Functions } & \multirow{2}{*}{ Reference } \\
\hline & & & & & & \\
\hline $\begin{array}{l}\text { myocardial } \\
\text { ischemia }\end{array}$ & mmu_circ_004295 & $\begin{array}{l}30 \text { min ischemia of } \\
\text { mouse heart }\end{array}$ & $6 / 6$ & up & $\begin{array}{l}\text { promotes cardiomyocyte } \\
\text { apoptosis }\end{array}$ & [90] \\
\hline $\begin{array}{l}\text { myocardial } \\
\text { ischemia }\end{array}$ & hsa_circ_0007623 & $\begin{array}{l}\text { ISO intraperitoneally } \\
\text { injected of mouse } \\
\text { heart }\end{array}$ & $6 / 6$ & up & $\begin{array}{l}\text { promotes myocardial repair } \\
\text { and improves cardiac function }\end{array}$ & [93] \\
\hline MIR & mmu_circ_006636 & $\begin{array}{l}60 \text { min ischemia } \\
\text { follow } 3 \mathrm{~h} / 1 \mathrm{~h} \\
\text { reperfusion mice } \\
\text { heart }\end{array}$ & $6 / 6$ & down & $\begin{array}{l}\text { protects the heart from } \\
\text { ischemia/reperfusion injury } \\
\text { and reduces myocardial } \\
\text { infarct sizes }\end{array}$ & [55] \\
\hline MIR & mmu_circ_101237 & $\begin{array}{l}\text { primary } \\
\text { cardiomyocyte of } \\
\text { mice }\end{array}$ & $3 / 3$ & up & $\begin{array}{l}\text { attenuates autophagy and cell } \\
\text { death in cardiomyocytes, and } \\
\text { reduces myocardial } \\
\text { infarct size }\end{array}$ & [56] \\
\hline MIR & hsa_circ_0060180 & $\begin{array}{l}\text { acute ischemic stroke } \\
\text { patients plasma }\end{array}$ & $26 / 26$ & down & participates in apoptosis & [91] \\
\hline OGD & hsa_circ_0002142 & $\begin{array}{l}\text { acute myocardial } \\
\text { ischemia human } \\
\text { blood }\end{array}$ & $25 / 25$ & up & $\begin{array}{c}\text { enhances OGD-induced cell } \\
\text { viability and migration, but } \\
\text { declines OGD-induced } \\
\text { apoptosis }\end{array}$ & [94] \\
\hline OGD & rno_circ_009421 & rats $\mathrm{H} 9 \mathrm{c} 2$ cells & $3 / 3$ & up & $\begin{array}{c}\text { releases OGD-induced } \\
\text { damage and down-regulates } \\
\text { apoptosis and autophagy }\end{array}$ & [95] \\
\hline OGD & hsa_circ_0010729 & $\begin{array}{l}\text { human } \\
\text { cardiomyocytes }\end{array}$ & $3 / 3$ & up & $\begin{array}{l}\text { silence of it could help protect } \\
\text { cardiomyocytes from } \\
\text { ischemic injury }\end{array}$ & [96] \\
\hline
\end{tabular}

Abbreviation: MIR, myocardial ischemia/reperfusion; OGD, oxygen glucose deprivation; ISO, isoproterenol.

Autophagy is a well-established conserved mechanism that was demonstrated to have a critical role in many physiological and pathological processes of cardiovascular diseases. Zhou et al. analyzed circRNAs from ischemia/reperfusion (I/R)-and shamtreated mouse heart tissue by microarray, and reported that autophagy-related circular RNA (ACR, mmu_circ_006636) was markedly decreased after MIR injury [55]. ACR could also attenuate autophagy and cell death in cardiomyocytes, and reduce myocardial infarct size by targeting the Pink1-mediated phosphorylation of FAM65B. Another circular RNA associated with autophagy in MI is mmu_circ_101237, which is encoded by the cyclin dependent kinase 8 (CDK8) gene [56]. Mmu_circ_101237 level was significantly increased by anoxia/reoxygenation (A/R) injury in a time-dependent manner and mmu_circ_101237 mediated apoptosis in cardiomyocytes by activating autophagy.

Compared with the myocardial ischemia model caused by ligating coronary arteries, isoproterenol (ISO)-induced acute myocardial ischemia is reversible and relatively harmless, but can mimic the beginning stage of ischemia. Next-generation sequencing revealed that hsa_circ_0007623 was upregulated in hypoxia-induced human umbilical-vein endothelial cells and ISO-induced acute myocardial ischemia mice [93]. The expression of hsa_circ_0007623 promotes myocardial repair and improved cardiac function, and showed potential as a new biomarker for acute myocardial ischemia.

A large number of studies applied oxygen glucose deprivation (OGD) treatment to construct myocardial ischemia models in vitro, and circRNA expressions in OGD-treated cardiomyocytes could provide some ideas in seeking a safe and reliable method for the prevention and treatment of ischemia injury [94]. In a study on myocardial ischemia patients' blood and OGD-treated rat H9c2 cells, the expression of circDENND2A (hsa_circ_0002142), which was highly expressed in HIF-1 $\alpha$ induced glioma cells, was both significantly elevated in myocardial ischemia patients and conspicuously enhanced under OGD treatment. In another study, OGD treatment also induced the high expression of circZNF292 (rno_circ_009421) in the H9c2 cell line, and the overexpression of circZNF292 could release 
OGD-induced damage to the cardiomyocyte such as the inhibition of proliferation, apoptosis, and autophagy [95]. Moreover, hsa_circ_0010729 is a newly discovered circRNA that is associated with the anoxia-caused cell growth of vascular endothelial cells. Researchers also found that hsa_circ_0010729 expression was upregulated in OGD-treated human cardiomyocytes, and its silencing could protect cardiomyocytes from ischemic injury [96,97].

\subsection{Arrhythmias}

Given that fatal arrhythmias are responsible for most sudden deaths, identifying novel biomarkers for the occur-rence of arrhythmias is an important goal for the clinical diagnosis and forensic identification of SCD [98]. Though atrial fibrillation (AF) is the most common type of arrhythmia in the general population, ventricular arrhythmia (VA) is the major mechanism of SCD in IHD $[57,98]$. Some studies revealed that circRNAs participate in AF by the identification and characterization of circRNA expression profiles, and provide novel biomarkers and potential therapeutic targets for AF [99]. However, the expression and function of circRNAs in VAs were not experimentally confirmed.

By analyzing circRNA expression profiles in AF patients and healthy controls by circRNA microarray, Jiang and colleagues identified 537 upregulated circRNAs and 199 downregulated circRNAs in the AF patients, and many interacted with AF-related microRNAs [57]. Wu et al. collected atrial tissue from $7 \mathrm{AF}$ patients and 7 matched controls, and identified a total of 280 circRNAs that were significantly differentially expressed by HiSeq/Proton RNA sequencing, including 46 upregulated and 234 downregulated, respectively [58]. After validation by real-time RT-qPCR on 35 pairs of AF patients and controls, two circRNAs, hsa_circ_24801 and hsa_circ_16247 showed significant dysregulation (Table 5). Expressed hsa_circ_0004113 and hsa_circ_0003965 levels were also consistent with Jiang's results [57]. Costa et al. performed an unbiased study analyzing the expression profile for circRNAs in left-atrial biopsies from 8 patients with paroxysmal and permanent $\mathrm{AF}$ and 6 controls in sinus rhythm by RNA sequence [59]. Forty circRNAs were exclusively detected in permanent AF samples, which were generated by the noncanonical splicing of 18 coding genes. Among them, hsa_circ_012664 was also confirmed in Wu's study [58]. In addition, scholars found 51 upregulated and 57 downregulated circRNAs by analyzing differential circRNA expression in atrial-tissue samples from patients with persistent AF with rheumatic heart disease and non-AF myocardium with normal hearts [60].

Table 5. Different expressions of circRNAs in atrial fibrillation validated by real-time RT-qPCR.

\begin{tabular}{|c|c|c|c|c|}
\hline \multirow{2}{*}{ CircRNAs } & \multirow{2}{*}{ Samples } & Sample Capacity & Expression & \multirow{2}{*}{ Reference } \\
\hline & & Case/Control & Regulation & \\
\hline $\begin{array}{l}\text { hsa_circ_100612, } \\
\text { hsa_circ_405917 }\end{array}$ & $\begin{array}{c}\text { human left atrial } \\
\text { appendages }\end{array}$ & $3 / 3$ & down & {$[57]$} \\
\hline $\begin{array}{l}\text { hsa_circ_008132, } \\
\text { hsa_circ_104052, } \\
\text { hsa_circ_101021, } \\
\text { hsa_circ_101020, } \\
\text { hsa_circ_102341, } \\
\text { hsa_circ_404747, } \\
\text { hsa_circ_002641, } \\
\text { hsa_circ_079477 }\end{array}$ & $\begin{array}{l}\text { human left atrial } \\
\text { appendages }\end{array}$ & $3 / 3$ & up & {$[57]$} \\
\hline $\begin{array}{l}\text { hsa_circ_16247, } \\
\text { hsa_circ_24801 }\end{array}$ & $\begin{array}{l}\text { human atrial } \\
\text { tissues }\end{array}$ & $35 / 35$ & up & [58] \\
\hline $\begin{array}{l}\text { hsa_circ_0005643, } \\
\text { novcl_circ_0026284, } \\
\text { novel_circ_0077334, } \\
\text { novel_circ_0068696, } \\
\text { novel_circ_0055884 }\end{array}$ & $\begin{array}{c}\text { human atrial } \\
\text { tissues }\end{array}$ & $15 / 15$ & up & {$[61]$} \\
\hline
\end{tabular}


Zhang and colleagues investigated the differentially expressed profiles of circRNAs in the atrial appendage tissue of 9 AF patients with 6 non-AF patients, and identified an expression difference between the left and right atrial appendages [61]. Results identified 147 remarkably dysregulated circRNAs in total, including 102 upregulated and 45 downregulated circRNAs. Among them, hsa_circ_0005643 and novel_circ_0077334 were significantly increased, and might be involved in pathophysiological AF progress by binding with miR-221-5p. Genomewide profiling also revealed atrial fibrillation-related circular RNAs in both the left and right atrial appendages of AF patients and healthy controls with sinus rhythm [62]. There were 374 upregulated and 104 downregulated circRNAs in total in the left atrial appendages, and 267 upregulated and 268 downregulated circRNAs in the right atrial appendages. Notably, 20 upregulated and 3 downregulated circRNAs were identified to be differentially expressed in both the left and the right atrial appendage. Among them, hsa_circ_0000075 and hsa_circ_0082096 participated in AF pathogenesis via the TGF-beta signaling pathway, and hsa_circ_ 0003965 was associated with the glucagon signaling pathway.

In a recent study on the four left atrial appendages of patients with nonvalvular persistent atrial fibrillation (NPAF) and four normal controls, a total of 296 significantly dysregulated circRNA transcripts were obtained via RNA sequencing, 238 upregulated and 58 downregulated; hsa_circ_002085 and hsa_circ_001321 showed potential as NPAF biomarkers [63]. Furthermore, Khan et al. screened the plasma circRNA expression profiles of 769 patients with and without postoperative atrial fibrillation (PoAF), and found that the expression of hsa_circRNA_025016 was upregulated in patients with newly onset AF after isolated off-pump coronary-artery bypass grafting, and positively correlated to fasting blood glucose [64]. Results demonstrated that plasma hsa_circ_025016 holds potential as a biomarker for the prediction of PoAF.

\subsection{Cardiomyopathy}

Two-thirds of SCD patients have an abnormal heart structure, and cardiomyopathy is a major component $[100,101]$. Cardiomyopathy is defined as a myocardial disorder in which the heart muscle is structurally and functionally abnormal, in the absence of coronaryartery disease, hypertension, valvular disease, and congenital heart disease, sufficient to cause the observed myocardial abnormality [101]. It can be classified as hypertrophic cardiomyopathy (HCM), dilated cardiomyopathy (DCM), arrhythmogenic right ventricular cardiomyopathy (ARVC), restrictive cardiomyopathy (RCM), and nonclassifiable cardiomyopathy [101]. Mohsin et al. detected circRNAs in the left ventricles of 2 DCM, 2 HCM, and 2 control individuals by whole-transcriptome sequencing, and identified 826 circRNAs from 7130 putative ones; 43 out of 826 were differentially expressed in DCM compared with control samples, and 60 circRNAs in HCM compared with the control samples [33]. Nearly $10 \%$ of altered circRNAs were expressed from the titin gene, which undergoes highly complex alternative splicing. More interestingly, after validation by real-time RTqPCR in a larger group of patients, a human panel of adult and fetal tissue samples, the authors confirmed the loss of circRNA formation from host genes CAMK2D (in DCM and $\mathrm{HCM}$ ) and titin (mainly in DCM) in disease, and disease-regulated changes in circRNA production are independent of transcriptional regulation. Siede and colleagues also validated dynamically changed circRNAs in eight patients with DCM and eight nonfailing control hearts, while circRNAs from SLC8A1, CHD7, and ATXN10 increased relative to their host gene expression, while circDNA6JC decreases in a disease state [65]. However, limited to sample numbers, the potential of these circRNAs as biomarkers for DCM has not been experimentally proven. Sonnenschein et al. analyzed the expression levels of several circRNAs in serum samples from 64 patients with HCM and 53 healthy controls, and found circTMEM56, circDNAJC6, and circMBOAT2 to be significantly lower in patients with $\mathrm{HCM}$ than they were in healthy controls [78]. Moreover, after stratifying patients into a nonobstructive (HNCM) group and an obstructive form (HOCM) group, the levels of circTMEM56 and circDNAJC6 circRNAs were negatively correlated with the severity of 
left ventricular obstruction and thickness of interventricular septum in the HOCM group, and could serve as indicators of disease severity in patients with HOCM. Results indicated good performance of these three circRNAs as HCM biomarkers, which may facilitate the clinical diagnosis of HCM.

In a mouse model of doxorubicin-induced cardiomyopathy (DOXIC), Zeng et al. found that circ-Amotl1 (hsa_circ_0004214) decreased in the cardiac tissue of mice after treating doxorubicin (Dox) for 14 days [66]. Circ-Amotl1 expression was also protective against apoptosis, the formation of collagen, and LV dysfunction. In a recent study on DOXIC, circular RNA sequencing was performed to profile circRNA expression in the hearts of cancer patients suffering from DOXIC and healthy donors. In total, 356 circRNAs were differentially expressed, namely, 207 upregulated and 149 downregulated [67]. Among the identified circRNAs, circITCH (hsa_circ_0001141) was consistently abundant in human primary cardiomyocytes, human left ventricle tissue, and human-induced pluripotent stemcell-derived cardiomyocytes (hiPSC-CMs). CircITCH level was lower in the hearts of cancer patients suffering from DOXIC than that in the hearts of DCM, HCM, and healthy donors. These findings also unveiled that circ-Amotl1 and circITCH might be novel diagnostic and therapeutic molecular targets that are amenable to DOXIC.

Diabetic cardiomyopathy is characterized by myocardial fibrosis, ventricular remodeling, and cardiac dysfunction, which is in the absence of hypertensive-heart, coronary-artery, and valvular-heart diseases [102]. The development of cardiac fibrosis is the key event in the pathogenesis of diabetic cardiomyopathy. Yang et al. identified that hsa_circ_0076631 levels increase in both high-glucose-treated cardiomyocytes and the serum of diabetic patients, and might facilitate precise gene diagnosis and therapeutic targets for diabetic cardiomyopathy [103]. Zhou et al. utilized circRNAs microarray analysis to detect the circRNA expression profile in a di-abetic mouse myocardium, and found that a total of 43 circRNAs were differentially expressed, including 24 upregulated circRNAs and 19 downregulated circRNAs, compared with the control groups [68]. Among them, mmu_circ_010567 was evidently upregulated and involved in the pathological process of myocardial fibrosis through negatively regulating miR-141 by targeting TGF- $\beta 1$. Another circRNA profiling array performed on a diabetic cardi-omyopathy mouse myocardium revealed 45 increased circRNAs and 31 decreased circRNAs [69]. Real-time RT-qPCR verified that mmu_circ_000203 was dramatically upregulated in this disease state, and enhanced the expressions of Col1a2, Col3a1, and $\alpha$-SMA in cardiac fibroblasts by acting as sponge to miR-26b-5p. Mechanistically, Li et al. also found that mmu_circ_000203 could exacerbate cardiac hypertrophy by suppressing miR-26b-5p and miR-140-3p binding to Gata4 [104]. These results suggested that mmu_circ_000203 might be a potential target for the prevention and treatment of cardiac fibrosis in diabetic cardiomyopathy.

Furthermore, of 643 circRNAs, scholars identified 114 upregulated and 151 downregulated that were expressed in the left ventricle myocardium of a mouse with alcoholic cardiomyopathy (ACM) [70]. These tremendous changes of circRNA expression in the heart further indicated that circRNAs might play significant biological roles in the development of ACM, but biomarker potential in ACM needs further study (Table 6).

\subsection{Myocarditis}

Myocarditis represents myocardial inflammation caused by diverse etiologies, and it is a major cause of SCD in children and young adults [106]. Zhang et al. analyzed the expression patterns of circRNAs in leukocytes separated from the peripheral blood samples of children with fulminant myocarditis and healthy volunteers by circRNA micro-array, and found that 3173 circRNAs showed differential expression, namely, 2281 upregulated and 892 downregulated circRNAs [71]. Among seven selected circRNAs, hsa_circ_0071542 was confirmed to be upregulated in the fulminant myocarditis group versus in control patients, while hsa_circ_0014350 was the contrary. In addition, hsa_circ_0071542 expression might be associated with the severity of myocardial damage, and serve as a biomarker of fulminant myocarditis. 
Shi et al. also found that circANKRD36 expression was prominently raised in lipopolysaccharide (LPS) pre-treated H9c2 cells, and silencing circANKRD36 alleviated LPS-induced apoptosis and inflammatory injury by inhibiting the p38MAPK/NF- $\mathrm{kB}$ pathway via upregulating miR-138 [105]. These findings uncovered a novel molecular mechanism of circANKRD36 and miR-138 effect on myocarditis, and provided an innovative target for clinical treatment.

Table 6. CircRNAs as potential biomarkers in cardiomyopathies and myocarditis validated by real-time RT-qPCR.

\begin{tabular}{|c|c|c|c|c|c|c|}
\hline \multirow{2}{*}{ Diseases } & \multirow{2}{*}{ CircRNA } & \multirow{2}{*}{ Samples } & \multirow{2}{*}{$\begin{array}{c}\text { Sample Capacity } \\
\text { Case/Control }\end{array}$} & \multirow{2}{*}{$\begin{array}{l}\text { Expression } \\
\text { Regulation }\end{array}$} & \multirow{2}{*}{ Functions } & \multirow{2}{*}{ Reference } \\
\hline & & & & & & \\
\hline ICM & hsa_circ_0006156 & $\begin{array}{l}\text { human heart } \\
\text { tissues }\end{array}$ & $7 / 4$ & down & $\begin{array}{l}\text { reduces left ventricular } \\
\text { functions }\end{array}$ & {$[52]$} \\
\hline DCM & $\begin{array}{l}\text { circNCX1 ratio }^{1}, \\
\text { circCHD7 ratio, } \\
\text { circATXN10 ratio }\end{array}$ & $\begin{array}{l}\text { human heart } \\
\text { tissues }\end{array}$ & $8 / 8$ & up & - & {$[65]$} \\
\hline DCM & circDNAJ6C ratio & $\begin{array}{l}\text { human heart } \\
\text { tissues }\end{array}$ & $8 / 8$ & down & - & {$[65]$} \\
\hline DOXIC & hsa_circ_0004214 & $\begin{array}{l}\text { mouse heart } \\
\text { tissues }\end{array}$ & $10 / 10$ & down & $\begin{array}{l}\text { educes the enlarged left } \\
\text { ventricle, and facilitates nuclear } \\
\text { translocation of AKT and PDK1 }\end{array}$ & {$[66]$} \\
\hline DOXIC & hsa_circ_0001141 & $\begin{array}{l}\text { human heart } \\
\text { tissues }\end{array}$ & $3 / 3$ & up & $\begin{array}{c}\text { ameliorates DOX-induced } \\
\text { cardiomyocyte injury and } \\
\text { dysfunction }\end{array}$ & [67] \\
\hline Diabetic CM & hsa_circ_0076631 & $\begin{array}{l}\text { diabetic patient } \\
\text { serum }\end{array}$ & $10 / 10$ & up & $\begin{array}{l}\text { mediates pyroptosis of diabetic } \\
\text { cardiomyopathy by functioning } \\
\text { as a competing } \\
\text { endogenous RNA }\end{array}$ & [103] \\
\hline Diabetic CM & mmu_circ_010567 & $\begin{array}{l}\text { mouse heart } \\
\text { tissues }\end{array}$ & $10 / 10$ & up & $\begin{array}{l}\text { participates in the pathogenesis } \\
\text { of myocardial fibrosis }\end{array}$ & {$[68]$} \\
\hline Diabetic CM & mmu_circ_000203 & $\begin{array}{l}\text { mouse heart } \\
\text { tissues }\end{array}$ & $8 / 8$ & up & $\begin{array}{l}\text { enhances the expression of } \\
\text { fibrosis-associated } \\
\text { genes by depressing targets of } \\
\text { miR-26b-5p, Col1a2 and CTGF, } \\
\text { in cardiac fibroblasts }\end{array}$ & [69] \\
\hline $\begin{array}{l}\text { fulminant } \\
\text { myocarditis }\end{array}$ & hsa_circ_0071542 & $\begin{array}{l}\text { human heart } \\
\text { tissues }\end{array}$ & $8 / 8$ & up & $\begin{array}{c}\text { may be associated with the } \\
\text { severity of fulminant } \\
\text { myocarditis }\end{array}$ & {$[71]$} \\
\hline myocarditis & circANKRD36 & rats $\mathrm{H} 9 \mathrm{c} 2$ cells & $3 / 3$ & up & $\begin{array}{l}\text { silencing it alleviates apoptosis } \\
\text { and inflammatory injury } \\
\text { induced by lipopolysaccharide }\end{array}$ & [105] \\
\hline
\end{tabular}

\footnotetext{
${ }^{1}$ Ratio refers to circRNA/(circRNA+LinearRNA). Abbreviation: ICM, ischemic cardiomyopathy; DCM, dilated cardiomyopathy; DOXIC,
} doxorubicin-induced cardiomyopathy; DOX, doxorubicin; CM, cardiomyopathy.

\section{CircRNAs as Novel Biomarkers in Postmortem SCD Diagnosis}

\subsection{CircRNA Applications in Forensic Medicine}

Due to the special molecular structure of circRNAs, forensic scientists pay attention to their study and seek to apply them to solving problems related to forensic identification. In forensic pathology, the analysis of the cause of death and the prediction of postmortem interval (PMI) are major foci, while individual identification and paternity tests are crucial for forensic genetics. Tu et al. evaluated the stability of multi-RNA markers in the heart, liver, and skeletal-muscle tissue of mice within 8 days after death, and concluded that miRNAs and circRNAs were more stable as reference genes than as other kinds of RNAs regarding PMI estimation [107]. They also established mathematical models of PMI estimation using the above selected reference genes and target biomarkers, which could increase PMI accuracy in advanced stages [108]. CircRNAs could also be used in the identification of forensically relevant tissue and body fluids on the basis of their high abundance, remarkable stability, and tissue-specific expression profiles [109]. In order to find tissue-specific 
circRNAs molecular markers, Gao et al. investigated 25 human tissue-specific circRNA expressions and tested circRNA stability. A total of 8 kinds of circRNAs were successfully verified in the heart, brain, liver, skin, and skeletal muscles.

The experiment results suggested that circRNAs had the ideal stability and different expression levels in human organs and tissue types, and could be used as new genetic markers for forensic humoral identification [110]. Zhang et al. investigated whether the inclusion of circRNAs in mRNA profiling improved the detection of biomarkers, including $\delta$-aminolevulinate synthase 2 (ALAS2) and matrix metallopeptidase 7 (MMP7), in bodyfluid identification. Results showed that the inclusion of circRNAs in mRNA profiling could facilitate the detection of mRNA markers in forensic body-fluid identification by using serial dilutions, mixed samples, menstrual bloodstains, and degraded and aged samples [111]. Further studies demonstrated that the expression of circRNAs could help in identifying common biofluids, even though all linear transcripts were completely erased by RNase $\mathrm{R}$ treatment $[109,112]$. In a recent study, researchers performed RNA sequence analysis on 13 biologically independent human peripheral whole blood specimens, and 7 age-correlated circRNA markers were identified. These results indicated that circRNAs could be used as a candidate marker for age prediction in peripheral blood, which provides theoretical basis for screening new molecular markers for age prediction in forensic medicine [113].

\subsection{Current Biomarkers in Postmortem SCD Diagnosis}

Various candidate biomarkers for SCD were discovered and applied in CVD diagnosis and treatment in clinical cardiology. However, there are relatively few globally recognized biomarkers for forensic postmortem SCD identification, though some were reported to improve diagnostic sensitivity, accuracy, and validity in forensic medicine. Biochemical markers such as cardiac troponin I (cTnI), creatine kinase $\mathrm{MB}$ (CK-MB), and N-terminal proB-type natriuretic peptide (NT-proBNP) are the most commonly used in postmortem SCD diagnosis in forensic practice $[11,114,115]$. The levels of these indicators in the blood or pericardial fluid are an important auxiliary for the diagnosis of SCD. Another kind of classical biomarker is inflammatory biomarker, such as C-reactive protein, high-sensitive C-reactive protein, and interleukin 6 [109]. Inflammation plays a pivotal role in the pathophysiology of most kinds of CVDs. Therefore, it is easy to speculate a link between inflammatory markers and SCD.

In the past decade, techniques of molecular biology also improved forensic medicine, especially in the determination of the cause of death [116]. Molecular-tissue changes in pathophysiology by immunohistochemical detection gradually participate in the postmortem identification of SCD. Several immunohistochemical markers, such as growth-associated protein-43 (GAF-43), connexin 43 (CX43), vascular endothelial growth factor (VEGF), and hypoxia-inducible factor 1-alpha (HIF-1 $\alpha$ ) were proposed for improving the postmortem detection of myocardial-ischemia-related SCD [117]. Genetic and epigenetic markers are also gaining attention. On the one hand, genomewide studies detected the association of many single-nucleotide polymorphisms with an increased risk of SCD [118-121]. On the other hand, epigenetic mechanisms, including DNA methylation, histone modification, and chromatin remodeling were also found to be crucial for the regulation of gene expression in SCD [122]. Some nc-RNAs were also reported to present high accuracy in discriminating SCD from AMI and healthy control [123].

\subsection{Opportunities and Challenges}

Studies on circRNAs as postmortem diagnostic biomarkers of SCD are lacking and face immense challenges, despite their tremendous potential as clinical CVD markers. An ideal biomarker needs to have high sensitivity and specificity, and should not be affected by many factors such as patient gender, age, lifestyle, and genetic background [124]. It would be even better if a biomarker could reflect the severity of the disease stage or even predict the outcome [26]. Furthermore, safety and noninvasiveness are the basic conditions for their wide clinical application. In this context, circRNAs are suitable biomarkers in CVD 
diagnosis. First, the presence of thousands of circRNAs was described in CVD with tissueand time-specific expressions, and many of them showed high sensitivity and specificity. Second, due to the closed circular molecule, circRNAs are resistant to RNA exonucleases, and hence have better stability than that of other types of ncRNAs [19]. Additionally, circRNAs are enriched in exosomes, which can be collected by several biological fluids such as blood, urine, saliva, breast milk, and semen [45]. Detecting the circulating circRNAs expression in body fluids not only facilitates the clinical diagnosis, but also provides the possibility for the detection of special forensic biological materials (such as pericardial and vitreous body fluids). Moreover, because of the competition with mRNA in the processing mechanism, tissue and body-fluid samples with few mRNA expression changes may have significant alteration of corresponding circRNA levels, which excavates new biomarkers [24,109]. However, more research on the exploration of circRNAs as potential biomarkers should be carried out on large amounts of demographic data. First, although the expression level of circular RNAs undergoes a great change during the occurrence of various cardiovascular diseases, patients' physiological conditions need to be more explicit, including criteria such as age, gender, diet habits, and genetic background. Second, standard operating procedures and guidelines for best practices, in addition to automated and standardized assays, are also needed, including the selection, collection, and treatment of samples, test methods on circRNA identification and quantification, and normalization for endogenous or external references. Third, the establishment of a reliable reference-value range can ultimately ensure the wide application of circRNAs as biomarkers in SCD.

One of the most important of these challenges is that samples in forensic medicine are often affected by postmortem changes; thus, some widely used biomarkers may have specific limitations due to hemolysis or degradation or be impaired by a wide variety of noncardiac causes [125-127]. Although the average half-life of a circular RNA can reach $50 \mathrm{~h}$, many factors, such as the length of the amplified products, primer specificity, and endogenous controls, can affect the actual detection level [37,107,127]. Good postmortem stability is important to determine whether a clinically validated circRNA can be used in forensic analysis. A previous study evaluated the stability of several circRNAs, including circ-AFF1, in the hearts of mice within 8 days after death, and concluded that, as reference genes, circRNAs were more stable than other kinds of RNAs are in dead bodies $[107,108]$. Studies also reported that circRNAs presented relatively consistent and stable expression profiles in formalin-fixed paraffin-embedded tissues compared with their corresponding linear transcripts [128]. However, real-world conditions are much more complicated than laboratory conditions, especially with postmortem cases. Using short amplicons and standardized RT-qPCR assays in autopsy cases might improve the possibility of performing accurate quantitative analysis of circRNAs [128]. On the plus side, forensic scientists can obtain sufficient tissue samples through autopsies, even including some unconventional samples such as pericardial fluid, which also expands the conditions for the selection of appropriate biomarkers. High throughput methods such as RNA sequencing and microarray analysis for the expression profile of circRNAs in cardiac tissue of SCD victims may be extremely valuable. The thorough macro- and histo-pathological postmortem investigations could also provide more clues for the application of circRNAs as novel biomarkers. So far, there is no research on circRNA expression in the pericardial fluid, which may be another direction of circRNAs as potential biomarkers in the postmortem diagnosis of SCD.

In conclusion, increasing evidence indicates that circRNAs emerge as novel biomarkers in clinical diagnosis of CVDs, and have the potential of being biomarkers for postmortem diagnosis of SCD in forensic medicine, even though several questions remain unanswered. Further studies are required to be carried out with this specific research purpose.

Funding: This research was funded by the National Natural Science Foundation of China (Grant Number 82002001) and the National Science Foundation of Liaoning Province (Grant Number 20180530004). 
Institutional Review Board Statement: Not applicable.

Informed Consent Statement: Not applicable.

Data Availability Statement: Not applicable.

Conflicts of Interest: The authors declare no conflict of interest.

\section{References}

1. Osman, J.; Tan, S.C.; Lee, P.Y.; Low, T.Y.; Jamal, R. Sudden cardiac death (SCD)—Risk stratification and prediction with molecular biomarkers. J. Biomed. Sci. 2019, 26, 39. [CrossRef]

2. Paratz, E.D.; Rowsell, L.; Zentner, D.; Parsons, S.; Morgan, N.; Thompson, T.; James, P.; Pflaumer, A.; Semsarian, C.; Smith, K.; et al. Cardiac arrest and sudden cardiac death registries: A systematic review of global coverage. Open Heart 2020, 7, e1195. [CrossRef]

3. Wong, C.X.; Brown, A.; Lau, D.H.; Chugh, S.S.; Albert, C.M.; Kalman, J.M.; Sanders, P. Epidemiology of sudden cardiac death: Global and regional perspectives. Heart Lung Circ. 2019, 28, 6-14. [CrossRef]

4. Isbister, J.; Semsarian, C. Sudden cardiac death: An update. Intern. Med. J. 2019, 49, 826-833. [CrossRef] [PubMed]

5. Kaneko, H.; Hara, M.; Mizutani, K.; Yoshiyama, M.; Yokoi, K.; Kabata, D.; Shintani, A.; Kitamura, T. Improving outcomes of witnessed out-of-hospital cardiac arrest after implementation of international liaison committee on resuscitation 2010 consensus: A nationwide prospective observational Population-Based study. J. Am. Heart Assoc. 2017, 6, e004959. [CrossRef]

6. Lai, H.; Choong, C.V.; Fook-Chong, S.; Ng, Y.Y.; Finkelstein, E.A.; Haaland, B.; Goh, E.S.; Leong, B.S.; Gan, H.N.; Foo, D.; et al. Interventional strategies associated with improvements in survival for out-of-hospital cardiac arrests in Singapore over 10 years. Resuscitation 2015, 89, 155-161. [CrossRef] [PubMed]

7. Kitamura, T.; Iwami, T.; Kawamura, T.; Nitta, M.; Nagao, K.; Nonogi, H.; Yonemoto, N.; Kimura, T. Nationwide improvements in survival from out-of-hospital cardiac arrest in Japan. Circulation 2012, 126, 2834-2843. [CrossRef]

8. Bray, J.E.; di Palma, S.; Jacobs, I.; Straney, L.; Finn, J. Trends in the incidence of presumed cardiac out-of-hospital cardiac arrest in Perth, Western Australia, 1997-2010. Resuscitation 2014, 85, 757-761. [CrossRef] [PubMed]

9. Grassi, S.; Campuzano, O.; Coll, M.; Brion, M.; Arena, V.; Iglesias, A.; Carracedo, A.; Brugada, R.; Oliva, A. Genetic variants of uncertain significance: How to match scientific rigour and standard of proof in sudden cardiac death? Leg. Med. 2020, 45, 101712. [CrossRef]

10. Chen, J.H.; Inamori-Kawamoto, O.; Michiue, T.; Ikeda, S.; Ishikawa, T.; Maeda, H. Cardiac biomarkers in blood, and pericardial and cerebrospinal fluids of forensic autopsy cases: A reassessment with special regard to postmortem interval. Leg. Med. 2015, 17, 343-350. [CrossRef]

11. Cao, Z.; Zhao, M.; Xu, C.; Zhang, T.; Jia, Y.; Wang, T.; Zhu, B. Diagnostic roles of postmortem cTn I and cTn T in cardiac death with special regard to myocardial infarction: A systematic literature review and Meta-Analysis. Int. J. Mol. Sci. 2019, 20, 3351. [CrossRef]

12. Morin, D.P.; Homoud, M.K.; Estes, N.R. Prediction and prevention of sudden cardiac death. Card. Electrophysiol. Clin. 2017, 9, 631-638. [CrossRef] [PubMed]

13. Sanger, H.L.; Klotz, G.; Riesner, D.; Gross, H.J.; Kleinschmidt, A.K. Viroids are single-stranded covalently closed circular RNA molecules existing as highly base-paired rod-like structures. Proc. Natl. Acad. Sci. USA 1976, 73, 3852-3856. [CrossRef] [PubMed]

14. Hsiao, K.Y.; Sun, H.S.; Tsai, S.J. Circular RNA-New member of noncoding RNA with novel functions. Exp. Biol. Med. 2017, 242, 1136-1141. [CrossRef]

15. Meng, X.; Li, X.; Zhang, P.; Wang, J.; Zhou, Y.; Chen, M. Circular RNA: An emerging key player in RNA world. Brief. Bioinform. 2017, 18, 547-557. [CrossRef] [PubMed]

16. Nigro, J.M.; Cho, K.R.; Fearon, E.R.; Kern, S.E.; Ruppert, J.M.; Oliner, J.D.; Kinzler, K.W.; Vogelstein, B. Scrambled exons. Cell 1991, 64, 607-613. [CrossRef]

17. Cocquerelle, C.; Daubersies, P.; Majerus, M.A.; Kerckaert, J.P.; Bailleul, B. Splicing with inverted order of exons occurs proximal to large introns. Embo. J. 1992, 11, 1095-1098. [CrossRef] [PubMed]

18. Capel, B.; Swain, A.; Nicolis, S.; Hacker, A.; Walter, M.; Koopman, P.; Goodfellow, P.; Lovell-Badge, R. Circular transcripts of the testis-determining gene Sry in adult mouse testis. Cell 1993, 73, 1019-1030. [CrossRef]

19. Lasda, E.; Parker, R. Circular RNAs: Diversity of form and function. RNA 2014, 20, 1829-1842. [CrossRef]

20. Werfel, S.; Nothjunge, S.; Schwarzmayr, T.; Strom, T.M.; Meitinger, T.; Engelhardt, S. Characterization of circular RNAs in human, mouse and rat hearts. J. Mol. Cell. Cardiol. 2016, 98, 103-107. [CrossRef]

21. Xu, T.; Wu, J.; Han, P.; Zhao, Z.; Song, X. Circular RNA expression profiles and features in human tissues: A study using RNA-seq data. BMC Genomics 2017, 18, 680. [CrossRef] [PubMed]

22. Hansen, T.B.; Jensen, T.I.; Clausen, B.H.; Bramsen, J.B.; Finsen, B.; Damgaard, C.K.; Kjems, J. Natural RNA circles function as efficient microRNA sponges. Nature 2013, 495, 384-388. [CrossRef] [PubMed]

23. Li, Z.; Huang, C.; Bao, C.; Chen, L.; Lin, M.; Wang, X.; Zhong, G.; Yu, B.; Hu, W.; Dai, L.; et al. Exon-intron circular RNAs regulate transcription in the nucleus. Nat. Struct. Mol. Biol. 2015, 22, 256-264. [CrossRef]

24. Li, Z.; Huang, C.; Bao, C.; Chen, L.; Lin, M.; Wang, X.; Zhong, G.; Yu, B.; Hu, W.; Dai, L.; et al. Corrigendum: Exon-intron circular RNAs regulate transcription in the nucleus. Nat. Struct. Mol. Biol. 2017, 24, 194. [CrossRef] [PubMed] 
25. Luo, J.; Liu, H.; Luan, S.; Li, Z. Guidance of circular RNAs to proteins' behavior as binding partners. Cell. Mol. Life Sci. 2019, 21, 4233-4243. [CrossRef]

26. Wang, W.; Wang, Y.; Piao, H.; Li, B.; Huang, M.; Zhu, Z.; Li, D.; Wang, T.; Xu, R.; Liu, K. Circular RNAs as potential biomarkers and therapeutics for cardiovascular disease. Peer] 2019, 7, e6831. [CrossRef] [PubMed]

27. Ashwal-Fluss, R.; Meyer, M.; Pamudurti, N.R.; Ivanov, A.; Bartok, O.; Hanan, M.; Evantal, N.; Memczak, S.; Rajewsky, N.; Kadener, S. CircRNA biogenesis competes with pre-mRNA splicing. Mol. Cell. 2014, 56, 55-66. [CrossRef]

28. Zhang, X.O.; Wang, H.B.; Zhang, Y.; Lu, X.; Chen, L.L.; Yang, L. Complementary sequence-mediated exon circularization. Cell 2014, 159, 134-147. [CrossRef]

29. Jeck, W.R.; Sorrentino, J.A.; Wang, K.; Slevin, M.K.; Burd, C.E.; Liu, J.; Marzluff, W.F.; Sharpless, N.E. Circular RNAs are abundant, conserved, and associated with ALU repeats. RNA 2013, 19, 141-157. [CrossRef] [PubMed]

30. Altesha, M.A.; Ni, T.; Khan, A.; Liu, K.; Zheng, X. Circular RNA in cardiovascular disease. J. Cell. Physiol. 2019, 234, 5588-5600. [CrossRef]

31. Conn, S.J.; Pillman, K.A.; Toubia, J.; Conn, V.M.; Salmanidis, M.; Phillips, C.A.; Roslan, S.; Schreiber, A.W.; Gregory, P.A.; Goodall, G.J. The RNA binding protein quaking regulates formation of circRNAs. Cell 2015, 160, 1125-1134. [CrossRef] [PubMed]

32. Zhang, Y.; Xue, W.; Li, X.; Zhang, J.; Chen, S.; Zhang, J.L.; Yang, L.; Chen, L.L. The biogenesis of nascent circular RNAs. Cell Rep. 2016, 15, 611-624. [CrossRef] [PubMed]

33. Khan, M.A.; Reckman, Y.J.; Aufiero, S.; van den Hoogenhof, M.M.; van der Made, I.; Beqqali, A.; Koolbergen, D.R.; Rasmussen, T.B.; van der Velden, J.; Creemers, E.E.; et al. RBM20 regulates circular RNA production from the titin gene. Circ. Res. 2016, 119, 996-1003. [CrossRef]

34. Chen, I.; Chen, C.Y.; Chuang, T.J. Biogenesis, identification, and function of exonic circular RNAs. Wiley Interdiscip. Rev. RNA 2015, 6, 563-579. [CrossRef]

35. Zhang, Y.; Zhang, X.O.; Chen, T.; Xiang, J.F.; Yin, Q.F.; Xing, Y.H.; Zhu, S.; Yang, L.; Chen, L.L. Circular intronic long noncoding RNAs. Mol. Cell 2013, 51, 792-806. [CrossRef] [PubMed]

36. Qu, S.; Zhong, Y.; Shang, R.; Zhang, X.; Song, W.; Kjems, J.; Li, H. The emerging landscape of circular RNA in life processes. RNA Biol. 2017, 14, 992-999. [CrossRef]

37. Enuka, Y.; Lauriola, M.; Feldman, M.E.; Sas-Chen, A.; Ulitsky, I.; Yarden, Y. Circular RNAs are long-lived and display only minimal early alterations in response to a growth factor. Nucleic Acids Res. 2016, 44, 1370-1383. [CrossRef]

38. Liu, Y.C.; Chiu, Y.J.; Li, J.R.; Sun, C.H.; Liu, C.C.; Huang, H.D. Biclustering of transcriptome sequencing data reveals human tissue-specific circular RNAs. BMC Genomics 2018, 19, 958. [CrossRef]

39. Zhou, Q.; Zhang, Z.; Bei, Y.; Li, G.; Wang, T. Circular RNAs as novel biomarkers for cardiovascular diseases. Adv. Exp. Med. Biol. 2018, 1087, 159-170.

40. Viereck, J.; Thum, T. Circulating noncoding RNAs as biomarkers of cardiovascular disease and injury. Circ. Res. 2017, 120, 381-399. [CrossRef]

41. Salzman, J. Circular RNA expression: Its potential regulation and function. Trends Genet. 2016, 32, 309-316. [CrossRef]

42. Ji, P.; Wu, W.; Chen, S.; Zheng, Y.; Zhou, L.; Zhang, J.; Cheng, H.; Yan, J.; Zhang, S.; Yang, P.; et al. Expanded expression landscape and prioritization of circular RNAs in mammals. Cell Rep. 2019, 26, 3444-3460. [CrossRef]

43. Kristensen, L.S.; Hansen, T.B.; Veno, M.T.; Kjems, J. Circular RNAs in cancer: Opportunities and challenges in the field. Oncogene 2018, 37, 555-565. [CrossRef] [PubMed]

44. Tan, W.L.; Lim, B.T.; Anene-Nzelu, C.G.; Ackers-Johnson, M.; Dashi, A.; See, K.; Tiang, Z.; Lee, D.P.; Chua, W.W.; Luu, T.D.; et al. A landscape of circular RNA expression in the human heart. Cardiovasc. Res. 2017, 113, 298-309. [CrossRef] [PubMed]

45. Wang, Y.; Liu, J.; Ma, J.; Sun, T.; Zhou, Q.; Wang, W.; Wang, G.; Wu, P.; Wang, H.; Jiang, L.; et al. Exosomal circRNAs: Biogenesis, effect and application in human diseases. Mol. Cancer 2019, 18, 116. [CrossRef] [PubMed]

46. Yu, F.; Tie, Y.; Zhang, Y.; Wang, Z.; Yu, L.; Zhong, L.; Zhang, C. Circular RNA expression profiles and bioinformatic analysis in coronary heart disease. Epigenomics 2020, 12, 439-454. [CrossRef]

47. Lin, F.; Zhao, G.; Chen, Z.; Wang, X.; Lv, F.; Zhang, Y.; Yang, X.; Liang, W.; Cai, R.; Li, J.; et al. CircRNAmiRNA association for coronary heart disease. Mol. Med. Rep. 2019, 19, 2527-2536.

48. Sun, Y.; Chen, R.; Lin, S.; Xie, X.; Ye, H.; Zheng, F.; Lin, J.; Huang, Q.; Huang, S.; Ruan, Q.; et al. Association of circular RNAs and environmental risk factors with coronary heart disease. BMC Cardiovasc. Disord. 2019, 19, 223. [CrossRef] [PubMed]

49. Zhao, Z.; Li, X.; Gao, C.; Jian, D.; Hao, P.; Rao, L.; Li, M. Peripheral blood circular RNA hsa_circ_0124644 can be used as a diagnostic biomarker of coronary artery disease. Sci. Rep. 2017, 7, 39918. [CrossRef] [PubMed]

50. Wang, L.; Shen, C.; Wang, Y.; Zou, T.; Zhu, H.; Lu, X.; Li, L.; Yang, B.; Chen, J.; Chen, S.; et al. Identification of circular RNA Hsa_circ_0001879 and Hsa_circ_0004104 as novel biomarkers for coronary artery disease. Atherosclerosis 2019, 286, 88-96. [CrossRef] [PubMed]

51. Li, X.; Zhao, Z.; Jian, D.; Li, W.; Tang, H.; Li, M. Hsa-circRNA11783-2 in peripheral blood is correlated with coronary artery disease and type 2 diabetes mellitus. Diab. Vasc. Dis. Res. 2017, 14, 510-515. [CrossRef]

52. Garikipati, V.; Verma, S.K.; Cheng, Z.; Liang, D.; Truongcao, M.M.; Cimini, M.; Yue, Y.; Huang, G.; Wang, C.; Benedict, C.; et al. Circular RNA CircFndc3b modulates cardiac repair after myocardial infarction via FUS/VEGF-A axis. Nat. Commun. 2019, 10, 4317. [CrossRef] 
53. Tan, J.; Gu, S.; Zheng, Y.; Yang, H. Expression profile of circular RNAs in myocardial ischemia/reperfusion with and without intermittent hypobaric hypoxia preconditioning. Sci. China Life Sci. 2019, 62, 1104-1106. [CrossRef] [PubMed]

54. Sun, H.; Wang, J.; Que, J.; Peng, Y.; Yu, Y.; Wang, L.; Ye, H.; Huang, K.; Xue, Y.; Zhou, Y.; et al. RNA sequencing revealing the role of AMP-activated protein kinase signaling in mice myocardial ischemia reperfusion injury. Gene 2019, 703, 91-101. [CrossRef] [PubMed]

55. Zhou, L.Y.; Zhai, M.; Huang, Y.; Xu, S.; An, T.; Wang, Y.H.; Zhang, R.C.; Liu, C.Y.; Dong, Y.H.; Wang, M.; et al. The circular RNA ACR attenuates myocardial ischemia/reperfusion injury by suppressing autophagy via modulation of the Pink1/FAM65B pathway. Cell Death Differ. 2019, 26, 1299-1315. [CrossRef]

56. Gan, J.; Yuan, J.; Liu, Y.; Lu, Z.; Xue, Y.; Shi, L.; Zeng, H. Circular RNA_101237 mediates anoxia/reoxygenation injury by targeting let7a5p/IGF2BP3 in cardiomyocytes. Int. J. Mol. Med. 2020, 45, 451-460.

57. Jiang, S.; Guo, C.; Zhang, W.; Che, W.; Zhang, J.; Zhuang, S.; Wang, Y.; Zhang, Y.; Liu, B. The integrative regulatory network of circRNA, microRNA, and mRNA in atrial fibrillation. Front. Genet. 2019, 10, 526. [CrossRef] [PubMed]

58. Wu, N.; Li, J.; Chen, X.; Xiang, Y.; Wu, L.; Li, C.; Zhang, H.; Tong, S.; Zhong, L.; Li, Y. Identification of long Non-Coding RNA and circular RNA expression profiles in atrial fibrillation. Heart Lung Circ. 2019, 19, 31521-31525. [CrossRef] [PubMed]

59. Costa, M.C.; Cortez-Dias, N.; Gabriel, A.; de Sousa, J.; Fiuza, M.; Gallego, J.; Nobre, A.; Pinto, F.J.; Enguita, F.J. CircRNA-miRNA cross-talk in the transition from paroxysmal to permanent atrial fibrillation. Int. J. Cardiol. 2019, 290, 134-137. [CrossRef]

60. Hu, M.; Wei, X.; Li, M.; Tao, L.; Wei, L.; Zhang, M.; Cheng, H.; Yuan, Y. Circular RNA expression profiles of persistent atrial fibrillation in patients with rheumatic heart disease. Anatol. J. Cardiol. 2019, 21, 2-10. [PubMed]

61. Zhang, Y.; Shen, H.; Wang, P.; Min, J.; Yu, Y.; Wang, Q.; Wang, S.; Xi, W.; Nguyen, Q.M.; Xiao, J.; et al. Identification and characterization of circular RNAs in atrial appendage of patients with atrial fibrillation. Exp. Cell Res. 2020, $389,111821$. [CrossRef] [PubMed]

62. Zhang, P.P.; Sun, J.; Li, W. Genome-wide profiling reveals atrial fibrillation-related circular RNAs in atrial appendages. Gene 2020, 728, 144286. [CrossRef] [PubMed]

63. Zhang, Y.; Ke, X.; Liu, J.; Ma, X.; Liu, Y.; Liang, D.; Wang, L.; Guo, C.; Luo, Y. Characterization of circRNAassociated ceRNA networks in patients with nonvalvular persistent atrial fibrillation. Mol. Med. Rep. 2019, 19, 638-650.

64. Khan, M.S.; Yamashita, K.; Sharma, V.; Ranjan, R.; Dosdall, D.J. RNAs and gene expression predicting postoperative atrial fibrillation in cardiac surgery patients undergoing coronary artery bypass grafting. J. Clin. Med. 2020, 9, 1139. [CrossRef]

65. Siede, D.; Rapti, K.; Gorska, A.A.; Katus, H.A.; Altmuller, J.; Boeckel, J.N.; Meder, B.; Maack, C.; Volkers, M.; Muller, O.J.; et al. Identification of circular RNAs with host gene-independent expression in human model systems for cardiac differentiation and disease. J. Mol. Cell. Cardiol. 2017, 109, 48-56. [CrossRef]

66. Zeng, Y.; Du, W.W.; Wu, Y.; Yang, Z.; Awan, F.M.; Li, X.; Yang, W.; Zhang, C.; Yang, Q.; Yee, A.; et al. A circular RNA binds to and activates AKT phosphorylation and nuclear localization reducing apoptosis and enhancing cardiac repair. Theranostics 2017, 7, 3842-3855. [CrossRef] [PubMed]

67. Han, D.; Wang, Y.; Zhang, J.; Dai, X.; Zhou, T.; Chen, J.; Tao, B.; Wang, Y.; Cao, F. The Tumor-Suppressive human circular RNA CircITCH sponges miR-330-5p to ameliorate Doxorubicin-Induced cardiotoxicity through upregulating SIRT6, survivin, and SERCA2a. Circ. Res. 2020, 127, e108-e125. [CrossRef]

68. Zhou, B.; Yu, J.W. A novel identified circular RNA, circRNA_010567, promotes myocardial fibrosis via suppressing miR-141 by targeting TGF-beta1. Biochem. Biophys. Res. Commun. 2017, 487, 769-775. [CrossRef]

69. Tang, C.M.; Zhang, M.; Huang, L.; Hu, Z.Q.; Zhu, J.N.; Xiao, Z.; Zhang, Z.; Lin, Q.X.; Zheng, X.L.; Yang, M.; et al. CircRNA_000203 enhances the expression of fibrosis-associated genes by derepressing targets of miR-26b-5p, Col1a2 and CTGF, in cardiac fibroblasts. Sci. Rep. 2017, 7, 40342. [CrossRef]

70. Yang, Y.; Chen, H.; Ding, N.; Wang, S.; Duan, Z.; Birnbaum, Y.; Ye, Y.; Qian, J. Expression profiling of circular RNAs and micrornas in heart tissue of mice with alcoholic cardiomyopathy. Cell. Physiol. Biochem. 2018, 46, 2284-2296. [CrossRef] [PubMed]

71. Zhang, L.; Han, B.; Wang, J.; Liu, Q.; Kong, Y.; Jiang, D.; Jia, H. Differential expression profiles and functional analysis of circular RNAs in children with fulminant myocarditis. Epigenomics 2019, 11, 1129-1141. [CrossRef]

72. Guo, Y.; Luo, F.; Liu, Q.; Xu, D. Regulatory non-coding RNAs in acute myocardial infarction. J. Cell. Mol. Med. 2017, 21, 1013-1023. [CrossRef]

73. Song, C.L.; Wang, J.P.; Xue, X.; Liu, N.; Zhang, X.H.; Zhao, Z.; Liu, J.G.; Zhang, C.P.; Piao, Z.H.; Liu, Y.; et al. Effect of circular ANRIL on the inflammatory response of vascular endothelial cells in a rat model of coronary atherosclerosis. Cell. Physiol. Biochem. 2017, 42, 1202-1212. [CrossRef] [PubMed]

74. Zhang, S.; Song, G.; Yuan, J.; Qiao, S.; Xu, S.; Si, Z.; Yang, Y.; Xu, X.; Wang, A. Circular RNA circ_0003204 inhibits proliferation, migration and tube formation of endothelial cell in atherosclerosis via miR-370-3p/TGFbetaR2/phosph-SMAD3 axis. J. Biomed. Sci. 2020, 27, 11. [CrossRef] [PubMed]

75. Vilades, D.; Martinez-Camblor, P.; Ferrero-Gregori, A.; Bar, C.; Lu, D.; Xiao, K.; Vea, A.; Nasarre, L.; Sanchez, V.J.; Leta, R.; et al. Plasma circular RNA hsa_circ_0001445 and coronary artery disease: Performance as a biomarker. FASEB J. 2020, 34, $4403-4414$. [CrossRef]

76. Zou, T.Y.; Li, L.; Huang, J.F.; Yang, B.; Wang, L.Y. Expression and clinical significance of circular RNA circTCF25 in patients with coronary artery disease. Mol. Cardio China 2018, 18, 2479-2483. (In Chinese) 
77. Zhao, Z.; Li, X.; Li, M. Response to Letter to the Editor entitled “Correct microarray analysis approaches in 'Hsa-circRNA11783-2 in peripheral blood is correlated with coronary artery disease and type 2 diabetes mellitus'”. Diab. Vasc. Dis. Res. 2018, 15, 169-170. [CrossRef]

78. Sonnenschein, K.; Wilczek, A.L.; de Gonzalo-Calvo, D.; Pfanne, A.; Derda, A.A.; Zwadlo, C.; Bavendiek, U.; Bauersachs, J.; Fiedler, J.; Thum, T. Serum circular RNAs act as blood-based biomarkers for hypertrophic obstructive cardiomyopathy. Sci. Rep. 2019, 9, 20350. [CrossRef] [PubMed]

79. Boateng, S.; Sanborn, T. Acute myocardial infarction. Dis. Mon. 2013, 59, 83-96. [CrossRef]

80. Garikipati, V.; Verma, S.K.; Cheng, Z.; Liang, D.; Truongcao, M.M.; Cimini, M.; Yue, Y.; Huang, G.; Wang, C.; Benedict, C.; et al. Author Correction: Circular RNA CircFndc3b modulates cardiac repair after myocardial infarction via FUS/VEGF-A axis. Nat. Commun. 2020, 11, 2234. [CrossRef] [PubMed]

81. Vausort, M.; Salgado-Somoza, A.; Zhang, L.; Leszek, P.; Scholz, M.; Teren, A.; Burkhardt, R.; Thiery, J.; Wagner, D.R.; Devaux, Y. Myocardial Infarction-Associated circular RNA predicting left ventricular dysfunction. J. Am. Coll. Cardiol. 2016, 68, 1247-1248. [CrossRef]

82. Salgado-Somoza, A.; Zhang, L.; Vausort, M.; Devaux, Y. The circular RNA MICRA for risk stratification after myocardial infarction. Int. J. Cardiol. Heart Vasc. 2017, 17, 33-36. [CrossRef] [PubMed]

83. Wang, X.; Guo, Z.; Ding, Z.; Mehta, J.L. Inflammation, autophagy, and apoptosis after myocardial infarction. J. Am. Heart Assoc. 2018, 7, e008024. [CrossRef] [PubMed]

84. Liu, X.; Wang, M.; Li, Q.; Liu, W.; Song, Q.; Jiang, H. CircRNA ACAP2 induces myocardial apoptosis after myocardial infarction by sponging miR-29. Minerva Med. 2020. [CrossRef]

85. Hansen, T.B.; Wiklund, E.D.; Bramsen, J.B.; Villadsen, S.B.; Statham, A.L.; Clark, S.J.; Kjems, J. MiRNA-dependent gene silencing involving Ago2-mediated cleavage of a circular antisense RNA. EMBO J. 2011, 30, 4414-4422. [CrossRef] [PubMed]

86. Geng, H.H.; Li, R.; Su, Y.M.; Xiao, J.; Pan, M.; Cai, X.X.; Ji, X.P. The circular RNA cdr1as promotes myocardial infarction by mediating the regulation of miR-7a on its target genes expression. PLoS ONE 2016, 11, e151753. [CrossRef] [PubMed]

87. Cai, L.; Qi, B.; Wu, X.; Peng, S.; Zhou, G.; Wei, Y.; Xu, J.; Chen, S.; Liu, S. Circular RNA Ttc3 regulates cardiac function after myocardial infarction by sponging miR-15b. J. Mol. Cell. Cardiol. 2019, 130, 10-22. [CrossRef]

88. Zhao, B.; Li, G.; Peng, J.; Ren, L.; Lei, L.; Ye, H.; Wang, Z.; Zhao, S. CircMACF1 attenuates acute myocardial infarction through miR-500b-5p-EMP1 axis. J. Cardiovasc. Transl. Res. 2020. [CrossRef]

89. Huang, S.; Li, X.; Zheng, H.; Si, X.; Li, B.; Wei, G.; Li, C.; Chen, Y.; Chen, Y.; Liao, W.; et al. Loss of Super-Enhancer-Regulated circRNA nfix induces cardiac regeneration after myocardial infarction in adult mice. Circulation 2019, 139, 2857-2876. [CrossRef]

90. Li, M.; Ding, W.; Tariq, M.A.; Chang, W.; Zhang, X.; Xu, W.; Hou, L.; Wang, Y.; Wang, J. A circular transcript of $n c x 1$ gene mediates ischemic myocardial injury by targeting miR-133a-3p. Theranostics 2018, 8, 5855-5869. [CrossRef]

91. Wang, S.; Chen, J.; Yu, W.; Deng, F. Circular RNA DLGAP4 ameliorates cardiomyocyte apoptosis through regulating BCL2 via targeting miR-143 in myocardial ischemia-reperfusion injury. Int. J. Cardiol. 2019, 279, 147. [CrossRef]

92. Bai, Y.; Zhang, Y.; Han, B.; Yang, L.; Chen, X.; Huang, R.; Wu, F.; Chao, J.; Liu, P.; Hu, G.; et al. Circular RNA DLGAP4 ameliorates ischemic stroke outcomes by targeting miR-143 to regulate endothelial- mesenchymal transition associated with Blood-Brain barrier integrity. J. Neurosci. 2018, 38, 32-50. [CrossRef]

93. Zhang, Q.; Sun, W.; Han, J.; Cheng, S.; Yu, P.; Shen, L.; Fan, M.; Tong, H.; Zhang, H.; Chen, J.; et al. The circular RNA hsa_circ_0007623 acts as a sponge of microRNA-297 and promotes cardiac repair. Biochem. Biophys. Res. Commun. 2020, 523, 993-1000. [CrossRef]

94. Shao, Y.; Zhong, P.; Sheng, L.; Zheng, H. Circular RNA circDENND2A protects H9c2 cells from oxygen glucose deprivationinduced apoptosis through sponging microRNA-34a. Cell Cycle 2020, 19, 246-255. [CrossRef] [PubMed]

95. Ren, Q.; Li, H.; Wang, X. The circular RNA ZNF292 alleviates OGD-induced injury in H9c2 cells via targeting BNIP3. Cell Cycle 2019, 18, 3365-3377. [CrossRef] [PubMed]

96. Jin, Q.; Chen, Y. Silencing circular RNA circ_0010729 protects human cardiomyocytes from oxygen-glucose deprivation-induced injury by up-regulating microRNA-145-5p. Mol. Cell. Biochem. 2019, 462, 185-194. [CrossRef] [PubMed]

97. Dang, R.Y.; Liu, F.L.; Li, Y. Circular RNA hsa_circ_0010729 regulates vascular endothelial cell proliferation and apoptosis by targeting the miR-186/HIF-1alpha axis. Biochem. Biophys. Res. Commun. 2017, 490, 104-110. [CrossRef] [PubMed]

98. Nishizawa, S.; Nakamura, T.; Hamaoka, T.; Matsumuro, A.; Sawada, T.; Matsubara, H. Lethal arrhythmia and corticosteroid insufficiency. Am. J. Emerg. Med. 2009, 27, 1161-1167. [CrossRef]

99. Hu, X.; Chen, L.; Wu, S.; Xu, K.; Jiang, W.; Qin, M.; Zhang, Y.; Liu, X. Integrative analysis reveals key circular RNA in atrial fibrillation. Front. Genet. 2019, 10, 108. [CrossRef] [PubMed]

100. Hertz, C.L.; Ferrero-Miliani, L.; Frank-Hansen, R.; Morling, N.; Bundgaard, H. A comparison of genetic findings in sudden cardiac death victims and cardiac patients: The importance of phenotypic classification. Europace 2015, 17, 350-357. [CrossRef]

101. Mckenna, W.J.; Maron, B.J.; Thiene, G. Classification, epidemiology, and global burden of cardiomyopathies. Circ. Res. 2017, 121, 722-730. [CrossRef] [PubMed]

102. Zhang, W.; Xu, W.; Feng, Y.; Zhou, X. Non-coding RNA involvement in the pathogenesis of diabetic cardiomyopathy. J. Cell. Mol. Med. 2019, 23, 5859-5867. [CrossRef]

103. Yang, F.; Li, A.; Qin, Y.; Che, H.; Wang, Y.; Lv, J.; Li, Y.; Li, H.; Yue, E.; Ding, X.; et al. A novel circular RNA mediates pyroptosis of diabetic cardiomyopathy by functioning as a competing endogenous RNA. Mol. Ther. Nucleic Acids 2019, 17, 636-643. [CrossRef] 
104. Li, H.; Xu, J.D.; Fang, X.H.; Zhu, J.N.; Yang, J.; Pan, R.; Yuan, S.J.; Zeng, N.; Yang, Z.Z.; Yang, H.; et al. Circular RNA circRNA_000203 aggravates cardiac hypertrophy via suppressing miR26b-5p and miR-140-3p binding to Gata4. Cardiovasc. Res. 2019, 116, 1323-1334. [CrossRef] [PubMed]

105. Shi, S.; Zhang, S.; Zhang, H.; Jin, Q.; Wu, D. Silencing circANKRD36 protects H9c2 cells against lipopolysaccharide-induced injury via up-regulating miR-138. Exp. Mol. Pathol. 2019, 111, 104300. [CrossRef] [PubMed]

106. Ali-Ahmed, F.; Dalgaard, F.; Al-Khatib, S.M. Sudden cardiac death in patients with myocarditis: Evaluation, risk stratification, and management. Am. Heart J. 2020, 220, 29-40. [CrossRef]

107. Tu, C.; Du, T.; Shao, C.; Liu, Z.; Li, L.; Shen, Y. Evaluating the potential of housekeeping genes, rRNAs, snRNAs, microRNAs and circRNAs as reference genes for the estimation of PMI. Forensic Sci. Med. Pathol. 2018, 14, 194-201. [CrossRef] [PubMed]

108. Tu, C.; Du, T.; Ye, X.; Shao, C.; Xie, J.; Shen, Y. Using miRNAs and circRNAs to estimate PMI in advanced stage. Leg. Med. 2019, 38, 51-57. [CrossRef] [PubMed]

109. Liu, B.; Song, F.; Yang, Q.; Zhou, Y.; Shao, C.; Shen, Y.; Zhao, Z.; Tang, Q.; Hou, Y.; Xie, J. Characterization of tissue-specific biomarkers with the expression of circRNAs in forensically relevant body fluids. Int. J. Leg. Med. 2019, 133, 1321-1331. [CrossRef] [PubMed]

110. Gao, A. The screening of human tissue-specific circ RNAs molecules and its application in forensic medicine. Hebei Med. Univ. 2020, 69. (In Chinese)

111. Zhang, Y.; Liu, B.; Shao, C.; Xu, H.; Xue, A.; Zhao, Z.; Shen, Y.; Tang, Q.; Xie, J. Evaluation of the inclusion of circular RNAs in mRNA profiling in forensic body fluid identification. Int. J. Leg. Med. 2018, 132, 43-52. [CrossRef]

112. Liu, B.; Yang, Q.; Meng, H.; Shao, C.; Jiang, J.; Xu, H.; Sun, K.; Zhou, Y.; Yao, Y.; Zhou, Z.; et al. Development of a multiplex system for the identification of forensically relevant body fluids. Forensic Sci. Int. Genet. 2020, 47, 102312. [CrossRef] [PubMed]

113. Wang, J. Identification of age-correlated circ RNA markers for the development of forensic age estimation models. Hebei Med. Univ. 2020, 83. (In Chinese)

114. Banon, R.; Hernandez-Romero, D.; Navarro, E.; Perez-Carceles, M.D.; Noguera-Velasco, J.A.; Osuna, E. Combined determination of B-type natriuretic peptide and high-sensitivity troponin I in the postmortem diagnosis of cardiac disease. Forensic Sci. Med. Pathol. 2019, 15, 528-535. [CrossRef] [PubMed]

115. Carvajal-Zarrabal, O.; Hayward-Jones, P.M.; Nolasco-Hipolito, C.; Barradas-Dermitz, D.M.; Calderon-Garciduenas, A.L.; LopezAmador, N. Use of cardiac injury markers in the postmortem diagnosis of sudden cardiac death. J. Forensic Sci. 2017, 62, 1332-1335. [CrossRef]

116. Madea, B.; Saukko, P.; Oliva, A.; Musshoff, F. Molecular pathology in forensic medicine-Introduction. Forensic Sci. Int. 2010, 203, 3-14. [CrossRef]

117. Aljakna, A.; Fracasso, T.; Sabatasso, S. Molecular tissue changes in early myocardial ischemia: From pathophysiology to the identification of new diagnostic markers. Int. J. Leg. Med. 2018, 132, 425-438. [CrossRef]

118. Arking, D.E.; Sotoodehnia, N. The genetics of sudden cardiac death. Annu. Rev. Genom. Hum. Genet. 2012, 13, 223-239. [CrossRef] [PubMed]

119. Ivanova, A.A.; Maksimov, V.N.; Orlov, P.S.; Ivanoshchuk, D.E.; Savchenko, S.V.; Voevoda, M.I. Association of the genetic markers for myocardial infarction with sudden cardiac death. Indian Heart J. 2017, 69, S8-S11. [CrossRef]

120. Andersen, J.D.; Jacobsen, S.B.; Trudso, L.C.; Kampmann, M.L.; Banner, J.; Morling, N. Whole genome and transcriptome sequencing of post-mortem cardiac tissues from sudden cardiac death victims identifies a gene regulatory variant in NEXN. Int. J. Leg. Med. 2019, 133, 1699-1709. [CrossRef] [PubMed]

121. Yang, Z.; Zhang, Q.; Yu, H.; Du, H.; Li, L.; He, Y.; Zhu, S.; Li, C.; Zhang, S.; Luo, B.; et al. Genetic association study of a novel indel polymorphism in HSPA1B with the risk of sudden cardiac death in the Chinese populations. Forensic Sci. Int. 2021, $318,110637$. [CrossRef] [PubMed]

122. Lei, H.; Hu, J.; Sun, K.; Xu, D. The role and molecular mechanism of epigenetics in cardiac hypertrophy. Heart Fail. Rev. 2020, 1-10. [CrossRef]

123. Pinchi, E.; Frati, P.; Aromatario, M.; Cipolloni, L.; Fabbri, M.; la Russa, R.; Maiese, A.; Neri, M.; Santurro, A.; Scopetti, M.; et al. MiR-1, miR-499 and miR-208 are sensitive markers to diagnose sudden death due to early acute myocardial infarction. J. Cell. Mol. Med. 2019, 23, 6005-6016. [CrossRef] [PubMed]

124. Shomanova, Z.; Ohnewein, B.; Schernthaner, C.; Hofer, K.; Pogoda, C.A.; Frommeyer, G.; Wernly, B.; Brandt, M.C.; Dieplinger, A.M.; Reinecke, H.; et al. Classic and novel biomarkers as potential predictors of ventricular arrhythmias and sudden cardiac death. J. Clin. Med. 2020, 9, 578. [CrossRef]

125. Ondruschka, B.; Woydt, L.; Bernhard, M.; Franke, H.; Kirsten, H.; Loffler, S.; Pohlers, D.; Hammer, N.; Dressler, J. Post-mortem in situ stability of serum markers of cerebral damage and acute phase response. Int. J. Leg. Med. 2019, 133, 871-881. [CrossRef] [PubMed]

126. Woydt, L.; Bernhard, M.; Kirsten, H.; Burkhardt, R.; Hammer, N.; Gries, A.; Dressler, J.; Ondruschka, B. Intra-individual alterations of serum markers routinely used in forensic pathology depending on increasing post-mortem interval. Sci. Rep. 2018, 8, 12811. [CrossRef]

127. Maeda, H.; Zhu, B.L.; Ishikawa, T.; Quan, L.; Michiue, T. Significance of postmortem biochemistry in determining the cause of death. Leg. Med. 2009, 1, S46-S49. [CrossRef] [PubMed]

128. Lv, Y.; Li, S.; Li, Z.; Tao, R.; Shao, Y.; Chen, Y. Quantitative analysis of noncoding RNA from paired fresh and formalin-fixed paraffin-embedded brain tissues. Int. J. Leg. Med. 2020, 134, 873-884. [CrossRef] 